\title{
ESPAÇOS LIVRES E ARBORIZAÇÃO: UMA ANÁLISE DO SUBUURBIO FERROVIÁRIO DO RIO DE JANEIRO
}

\author{
OPEN SPACES AND AFFORESTATION: \\ AN ANALISYS OF THE SUBURBAN RAILWAY OF RIO DE JANEIRO \\ Bruno Ragi Eis Mendonça \\ Vera Regina Tângari \\ Virgínia Maria Nogueira Vasconcellos
}

\begin{abstract}
Resumo
O subúrbio ferroviário da Cidade do Rio de Janeiro, localizado na Área de Planejamento 3, possui a maior concentração de população, número de domicílios e densidade demográfica dentre as áreas de planejamento da cidade, assim como o maior percentual de residentes em assentamentos precários. Destacam-se ainda, a elevada ocupação do solo e a consequente carência de espaços livres públicos. Este artigo busca apresentar a análise multi-métodos de identificação, quantificação e categorização dos espaços livres e da arborização existentes nos bairros do subúrbio ferroviário carioca. Em uma região consolidada, altamente adensada e caracterizada por elevadas médias de temperatura, o sistema de espaços livres públicos e privados e a arborização se apresentam como importantes elementos para melhoria do microclima, atuando, de maneira compensatória, às deficiências existentes na estrutura urbana local. Espera-se que tal análise possa ser instrumento útil e capaz de evidenciar a relevância da vegetação no sistema de espaços livres, agindo de forma colaborativa com as políticas públicas de gestão do território e de qualificação da paisagem.
\end{abstract}

Palavras-chave: Espaços Livres. Arborização. Subúrbio Ferroviário. Morfologia Urbana. Rio de Janeiro.

\section{ABSTRACT}

The railway suburb of Rio de Janeiro (Planning area 3 - AP3) presents the highest population density, number of households of the city, as well as the highest number of residents in precarious conditions. Furthermore, this area is negatively marked by an intense land occupation, mostly irregular, and a lack of public open spaces. In this context, our research used a multi-method analysis for identifying, quantifying and categorizing the open spaces and afforestation of the Rio de Janeiro railway suburban neighborhoods. In such a consolidated area like the AP3, which is densely occupied and has high average temperatures, the private and public open spaces and their afforestation are important to regulate the microclimate, compensating for the poor local urban infrastructure. The analysis highlights the importance of preserving the vegetation in open spaces system, presenting how those spaces can be used as an important tool for future urban planning actions, in collaboration with public policies for the improvement of the landscape. Keywords: Open Spaces. Afforestation. Railway Suburbs. Urban Morphology. Rio de Janeiro. 


\section{O Subúrbio Ferroviário no Rio de Janeiro}

No sentido original da categoria subúrbio, esse espaço geográfico é considerado um território situado à margem ou em áreas periféricas à cidade. Espaço esse produzido junto à cidade, mas que devido à sua localização geográfica, os tipos construtivos e usos são dissociáveis do espaço considerado urbano (FERNANDES, 2011). Na cidade do Rio de Janeiro do século XIX, os subúrbios foram ocupados por grandes latifúndios de propriedade religiosa ou particular, pertencentes às ordens da Igreja Católica ou aos senhores de engenhos e fazendas, em sua maior parte herdeiros das capitanias hereditárias, determinadas no século XVI. Após a chegada da Coroa Portuguesa, em 1808 e a expulsão dos padres jesuítas, que detinham grandes parcelas de terras na então Província do Rio de Janeiro, o controle dessas terras reverteu-se para a Coroa e para os membros abastados da Corte Portuguesa. Até o final do século XIX, as regiões suburbanas e afastadas do centro do povoado urbano serviam de áreas de produção agrícola e de moradia para membros das classes de rendas altas e médias, que habitavam chácaras e mansões e que possuíam condições de locomoção até as regiões centrais. Apenas no início do século XX, com o adensamento populacional e o parcelamento dos lotes para fins residenciais ocorre uma ocupação de caráter mais popular no perímetro da cidade formal (FRIDMAN, 1999).

O período entre 1870 e 1920 foi então caracterizado pela primeira fase de expansão acelerada da malha urbana carioca em direções qualitativamente distintas (Figura 1). As ferrovias e as linhas de bondes foram potenciais indutores de ocupação desse território, até então longínquo e inacessível por grande parte da população. "Nos cem anos que vão da metade do século XIX à metade do século XX, algumas áreas conhecem a implantação de um meio técnico, meio mecanizado, que altera a definição do espaço e modifica as condições de seu uso" (SANTOS, 2008, p. 48).

Os trens passaram a servir áreas ainda fracamente integradas a cidade, que se abriam então àqueles que podiam se dar ao luxo de morar fora da área central, mas não podiam arcar com os custos, já elevados, dos terrenos da Glória, Botafogo ou Tijuca; já os bondes permitiram o êxodo cada vez maior dos que podiam arcar com o ônus, mas mantinham-se no centro por falta de meio de transporte rápido e regular (ABREU, 2013, p. 43).

A gênese do subúrbio ferroviário carioca foi diretamente influenciada pela criação da Estrada de Ferro Central do Brasil (EFCB), que teve seu primeiro trecho inaugurado, em 1858. Com a máquina a vapor operante e o primeiro surto fabril no país, iniciado a partir de 1880, as fábricas antes implantadas em regiões mais afastadas se aproximaram da área urbana da cidade, instalando-se em arrabaldes, como Tijuca, São Cristóvão, Engenho Novo e Bangu, às margens da ferrovia (ABREU, 2013). O serviço de transporte de passageiros prestado pelos trens cariocas foi implantado por volta de 1870 e teve seu maior período de expansão até 1930 (LINS, 2010).

Por se tratar da linha que inicialmente realizava o transporte de passageiros, a Estrada de Ferro D. Pedro II, atual EFCB (destaque em amarelo na Figura 2), foi a que mais influenciou a ocupação do território na época, sendo um eixo estruturante e vetor de crescimento residencial do subúrbio ferroviário, principalmente nas áreas lindeiras às estações de trem. Segundo Abreu (2013), a inauguração do primeiro trecho da Estrada de Ferro D. Pedro II, que ligava a freguesia de Santana a Queimados, e a inauguração das estações de Cascadura e Engenho Novo, incentivaram, de imediato, a ocupação do espaço entre as estações e o centro da cidade. Já os subúrbios dos ramais Linha Auxiliar, Rio d'Ouro e Leopoldina (em laranja, azul e vermelho, respectivamente) foram impulsionados pela atividade industrial e o processo de intensificação de ocupação dessas regiões foi tardio e, portanto, diferenciado.

A identidade entre subúrbio e transporte ferroviário é tão marcante que exige um olhar bem acurado com relação ao estudo dessas áreas. Particularmente, na cidade do Rio de Janeiro, não se denomina subúrbio onde não existe o trem, mesmo que sejam áreas periféricas, dotadas de características próprias ao termo. Tal especificidade da ideia de subúrbio, no Rio de Janeiro, só assumiu tal condição quando passou a ser definida por três noções básicas: "o trem como meio de transporte, o predomínio da 


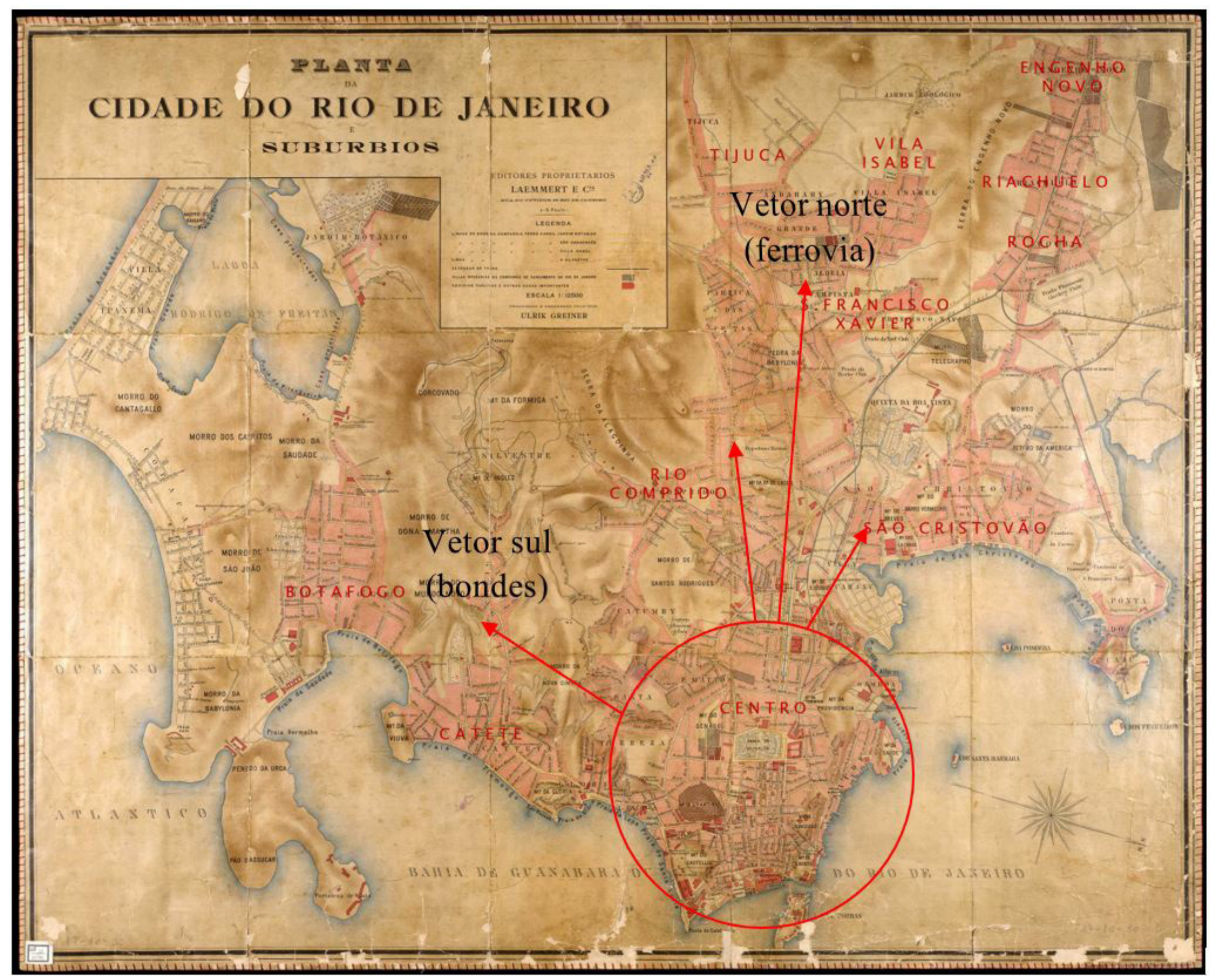

Figura 1 - Planta da Cidade do Rio de Janeiro e o surgimento dos subúrbios. Garriga, Antônio José Fausto, 1875 Fonte: Acervo Digital da Biblioteca Nacional. Adaptado pelo autor. 


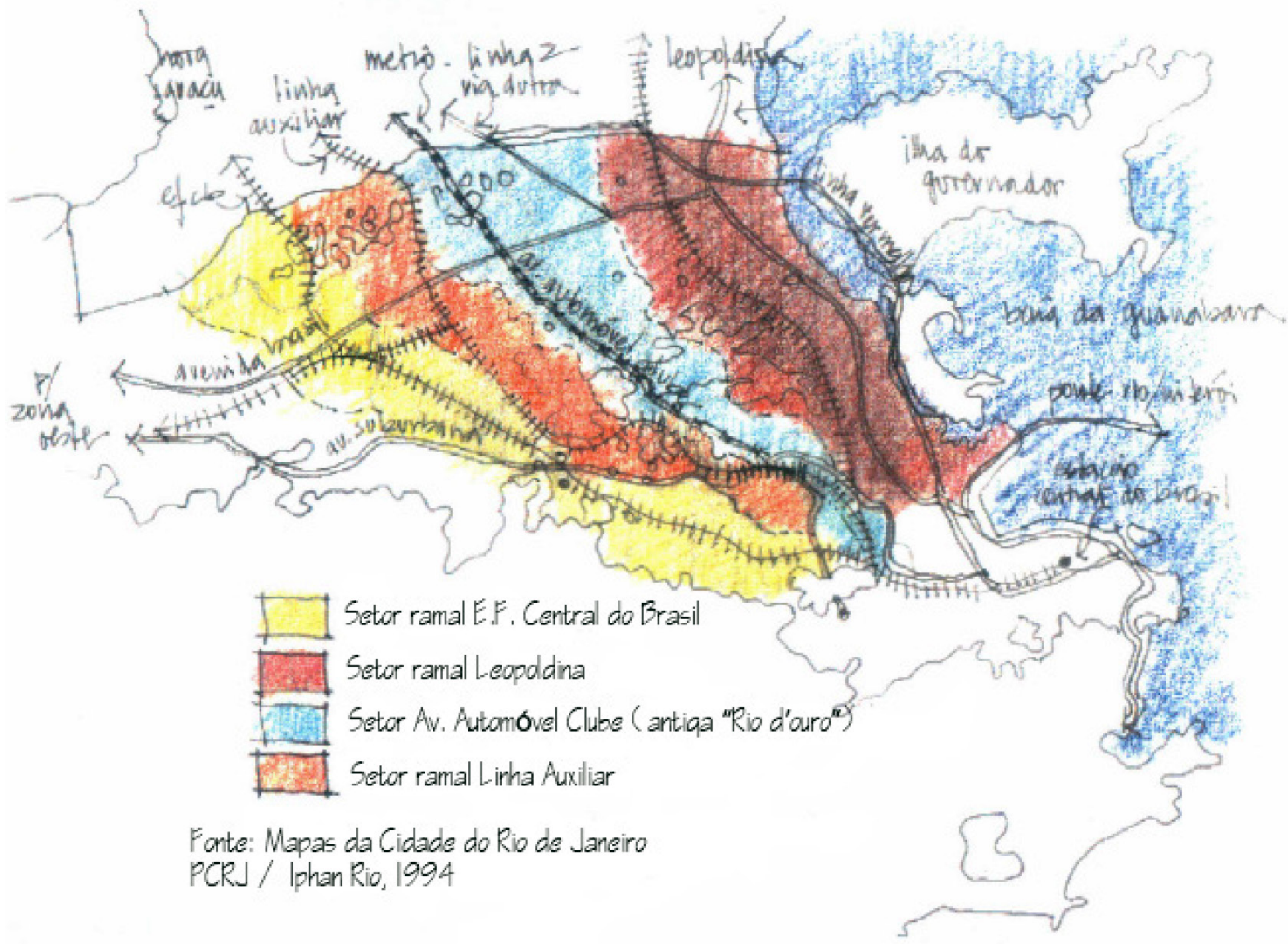

Figura 2 - Croqui dos setores ferroviários no Rio de Janeiro. Fonte: TÂNGARI, 1999, p. 252. 
população menos favorecida e a dependência e relações íntimas e frequentes com o Centro da Cidade" (SOARES, 1960 apud FERNADES, 2011, p. 37). Fernandes (2011) vê nesse "rapto ideológico" a justificativa para a construção de uma visão negativa e desqualificadora do subúrbio ferroviário, pois, segundo o autor, em meados do século XIX, os subúrbios da Estrada de Ferro figuravam como lugares salubres do ponto de vista ambiental e dotados de ambiências fortemente adequadas à sua ocupação, em uma cidade que apresentava grandes problemas de infraestrutura em seu centro urbano.

\subsection{A TRANSFORMAÇÃO DA PAISAGEM SUBURBANA}

Diante do relato histórico da conformação do território periférico ao centro da cidade do Rio de Janeiro, percebe-se que o subúrbio ferroviário, em sua gênese, possuía um caráter completamente diferente do que apresenta em dias atuais. Não só era percebido de outra maneira, como também apresentava uma estrutura de ocupação do solo e características territoriais bem distintas (Figura 3). Vale identificar em que momento da história da cidade essas mudanças drásticas ocorreram.

A partir das reformas iniciadas por Pereira Passos em 1903, nos moldes urbanísticos da capital francesa, emergiu uma nova organização espacial de ocupação que viria a se consolidar e a corroborar para o adensamento suburbano. Novos bairros surgiram a partir de povoamentos ocupados tanto por operários quanto por parte da população pobre, agora desalojada do antigo centro da cidade, devido às obras instaladas nessa região, que visavam ao seu "embelezamento". Sem padrões urbanísticos e na ausência de uma política eficaz de realocação, segundo descreve Nestor Goulart dos Reis (1977, p. 53), "uma configuração espontânea de ocupação tomou forma: ruas mal traçadas, abertas em terrenos acidentados, em terra, sem meios-fios, iam surgindo por todos os lados. Construções novas eram feitas nos lotes inadequados e desprovidos de alinhamentos".

O caráter funcionalista dos subúrbios foi capaz de exercer ainda influência sobre planos urbanos elaborados para a cidade
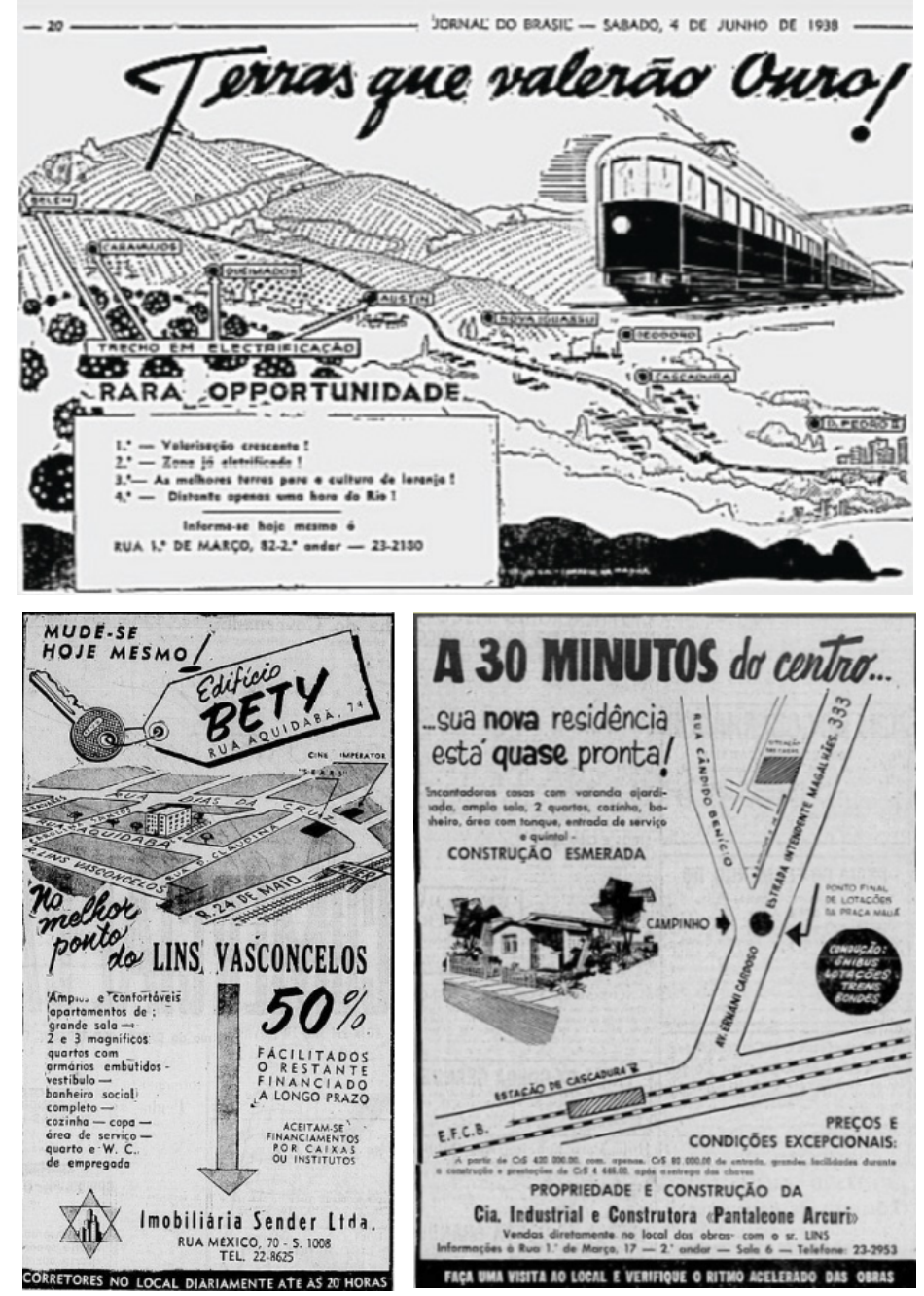

Figura 3 - Anúncios de venda de lotes em áreas próximas ao traçado ferroviário revelavam a baixa densidade construída e o predomínio dos espaços livres, sendo os terrenos situados próximo aos caminhos de ferro considerados bons investimentos. A primeira imagem data de 1938 e as demais de 1958

Fonte: http://www.estacoesferroviarias.com.br/efcb_rj_linha_centro/efcb_linhadocentro_rj.htm;

Acesso em: 18 mar. 2020 


\section{MUNICIPIO DO RIO DE JANEIRO: ZONEAMENTO INDUSTRIAL}

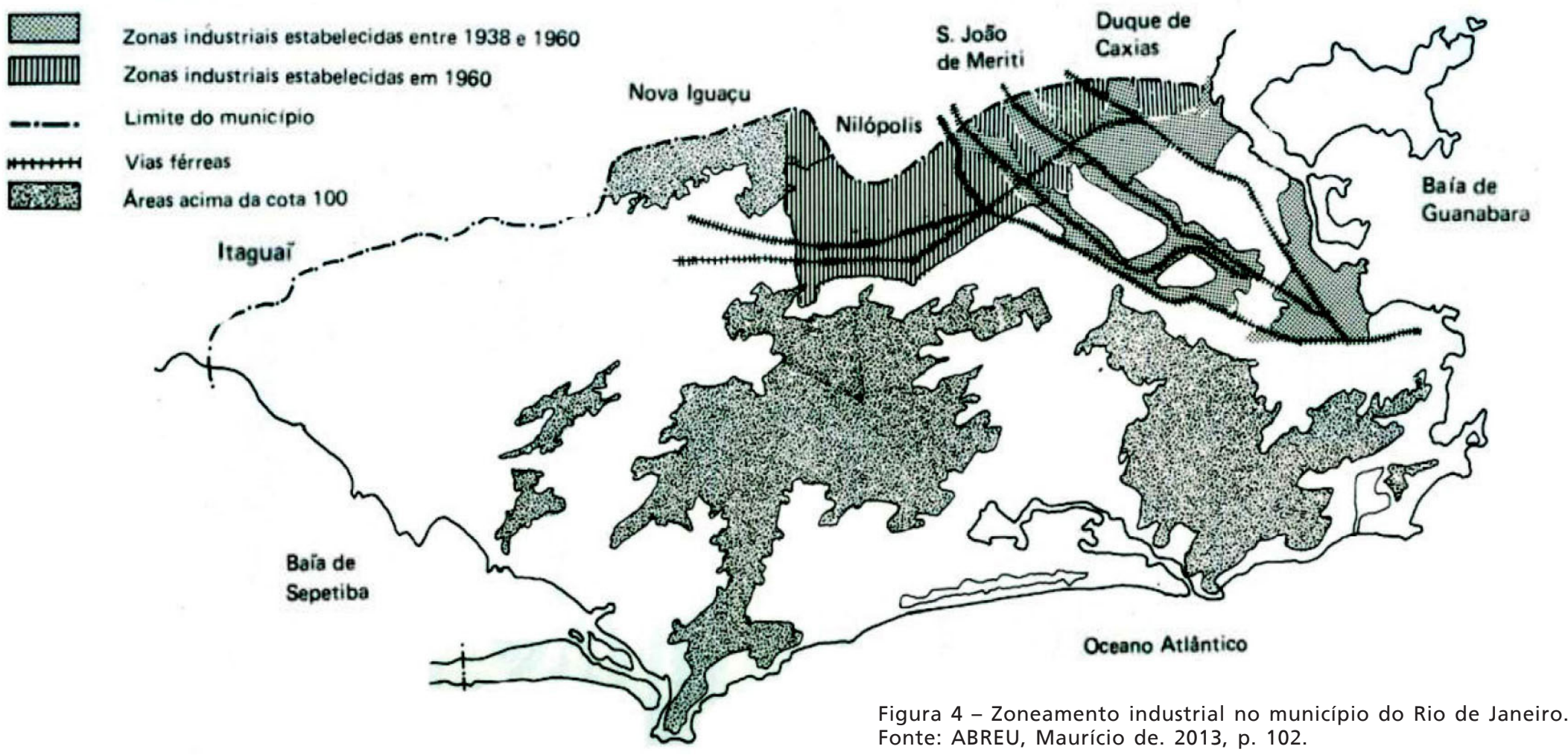

do Rio de Janeiro, como o Plano Agache. O arquiteto francês Alfred Agache, contratado pelo então Prefeito Antônio Prado Júnior, ao final da década de 1920, sugeriu a adoção de uma política urbana que privilegiasse a construção de habitações baratas nos subúrbios ${ }^{1}$, que também seriam dotados de um mínimo de infraestrutura básica. O plano, apesar de não implantado, na prática, oficializava a dicotomia entre burguesia $\times$ proletariado existente na cidade do Rio de Janeiro e preconizava de fato a necessidade de controlar o processo de reprodução da força de trabalho, o que asseguraria também, a separação espacial das classes sociais (ABREU, 2013, p. 87).

1 Aos subúrbios, denominados pelo plano de "bairros operários", foram previstas apenas soluções de funcionalidade, referindo-se aí apenas à ampliação dos sistemas ferroviário e metroviário, proporcionando acessibilidade a centros de emprego localizados na Zona Central da Cidade.
Já em 1930, a partir da ação do Estado em políticas de saneamento e da homologação do Decreto $n^{\circ} 6.000 / 1937$, iniciou-se um processo de ocupação industrial da região suburbana do Rio de Janeiro. O Decreto definiu uma zona industrial, nas zonas norte e nordeste (Figura 4), excluindo tal uso das zonas sul e central do Rio de Janeiro, por estarem essas afastadas das vias de comunicação ferroviárias com São Paulo e Minas Gerais e das principais linhas de energia elétrica. Impedidas de se expandir nessas regiões, as indústrias passaram então a lotear seus antigos terrenos, e instalaram-se em definitivo em regiões incentivadas. A partir do zoneamento industrial, as novas áreas apresentaram, na década seguinte, um crescimento vertiginoso não só de estabelecimentos fabris como de população (ABREU, 2013). 


\subsection{A área de planejamento 3 - AP3}

A partir de 1981 surge então a necessidade de divisão setorial para coordenação e planejamento na Cidade levando à sua compartimentação, que passou a ser sua base administrativa atual. Neste momento, iniciou-se a codificação institucional das regiões administrativas quando, pela primeira vez, foram oficializados os limites dos bairros. Em 1992, o Plano Diretor, criado através da Lei Complementar $n^{\circ} 16$ de 1992 e chamado de Plano Diretor Decenal, dividia o Rio de Janeiro em cinco Áreas de Planejamento, mas continuou a denominar como "suburbana" uma grande faixa que ladeava as linhas de trem. Apenas em 2011, a Prefeitura substituiu a expressão "zona suburbana" para nomear a Área de Planejamento 3 (AP3), que foi então inserida em uma das Macrozonas de Macroplanejamento do novo Plano Diretor (Figura 5), nomeado Plano Diretor de Desenvolvimento Urbano Sustentável do Município do Rio de Janeiro, homologado através da Lei Complementar n. ${ }^{\circ} 111$ de $1^{\circ}$ de fevereiro de 2011.
A AP3 corresponde a 16,6\% (INSTITUTO..., 2011) do território municipal, e é atualmente, subdividida em 13 Regiões Administrativas (RA) que são conjuntos de bairros vizinhos agrupados por suas semelhanças em relação a características morfológicas e socioambientais (Figura 6): Anchieta, Complexo do Alemão, Ilha do Governador, Inhaúma, Irajá, Jacarezinho, Madureira, Maré, Méier, Pavuna, Penha, Ramos e Vigário Geral.

É ainda a AP3 a detentora dos maiores índices de concentração populacional, domicílios e densidade demográfica em comparação com as demais áreas da cidade. Segundo os dados do censo realizado em 2010 pelo Instituto Brasileiro de Geografia e Estatística (IBGE), a região concentrava 2.440 .118 habitantes (38\% do total de habitantes da cidade), distribuídos em 8.608.310 domicílios ( $36 \%$ do total de domicílios da cidade) com uma densidade demográfica bruta de 119,91 habitantes/ha (Figura 7).

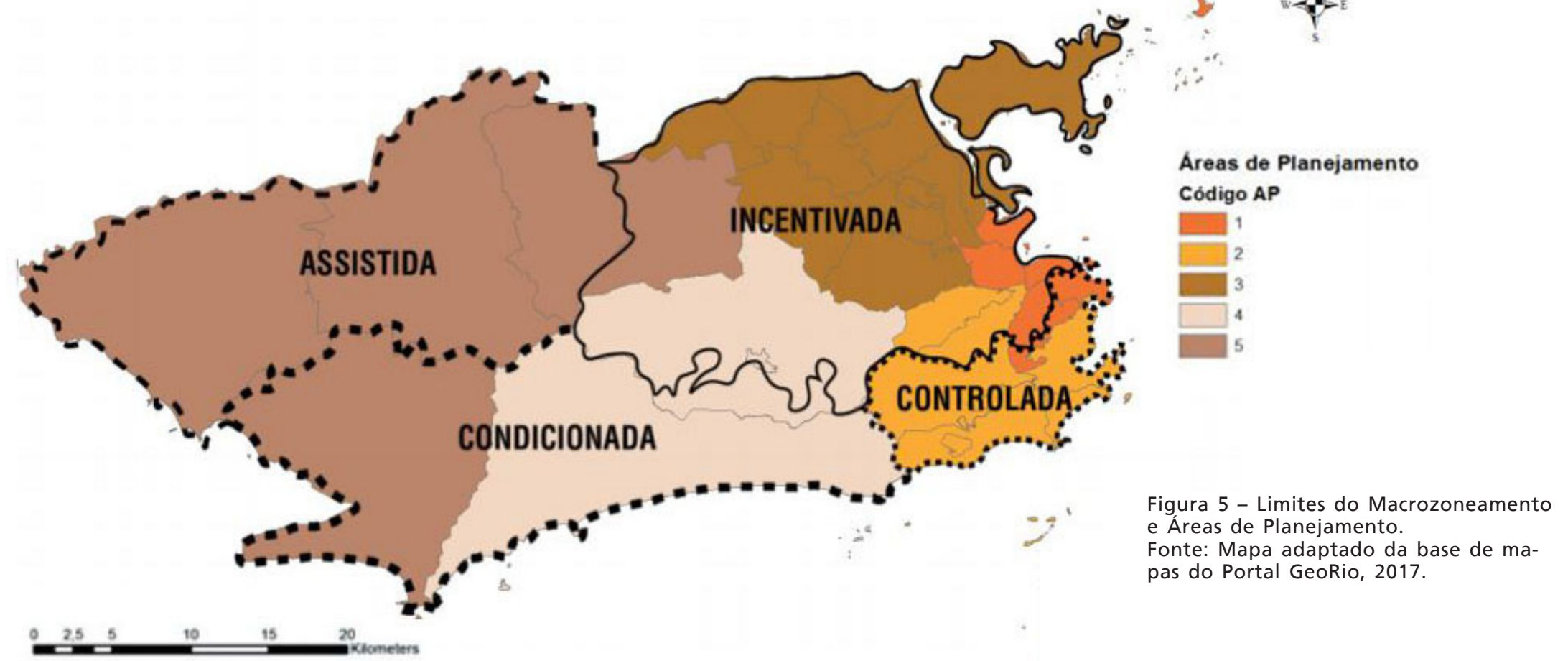




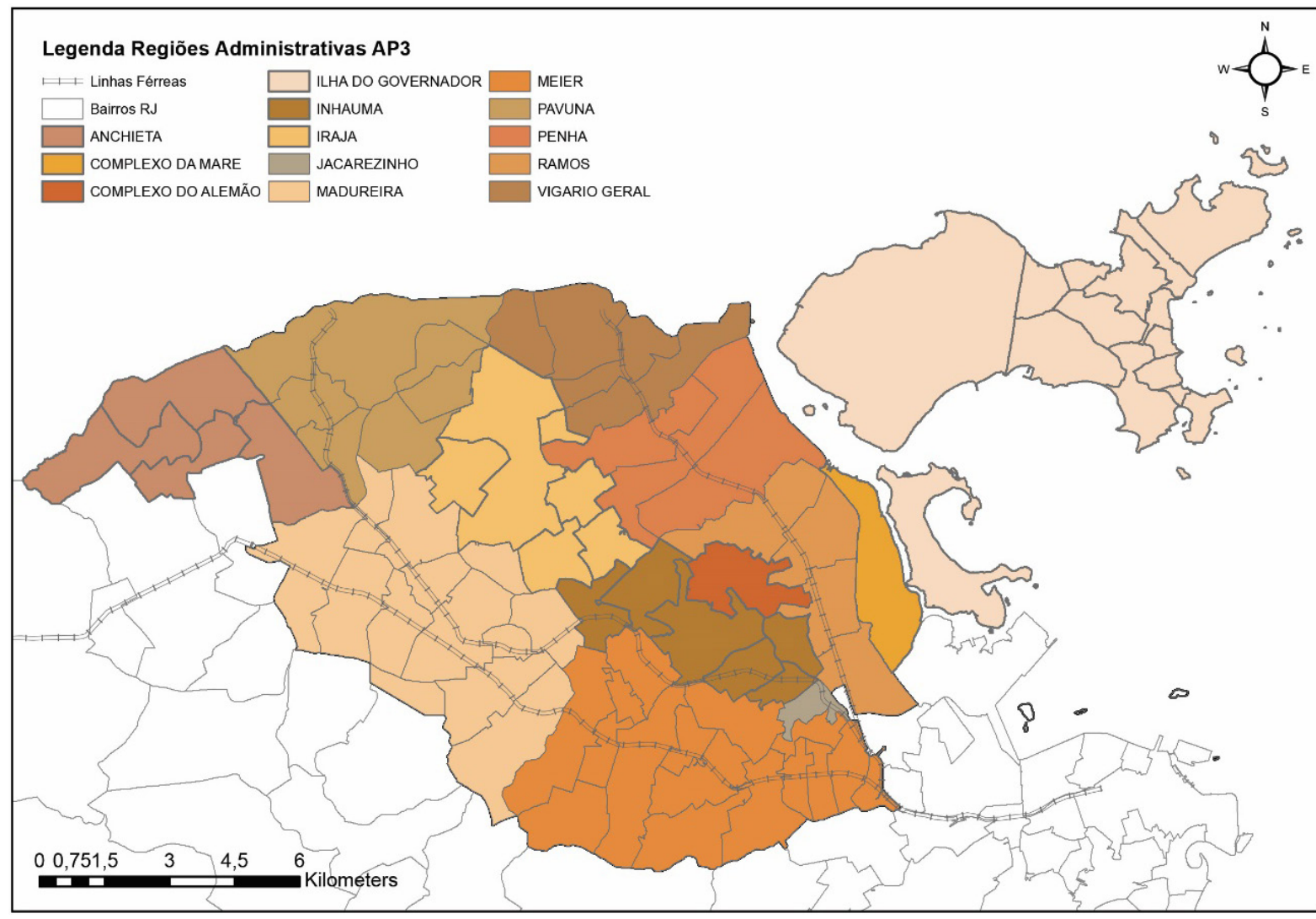

Figura 6 - Regiões Administrativas da AP3.

Fonte: Mapa adaptado da base de mapas do Portal GeoRio, 2017.

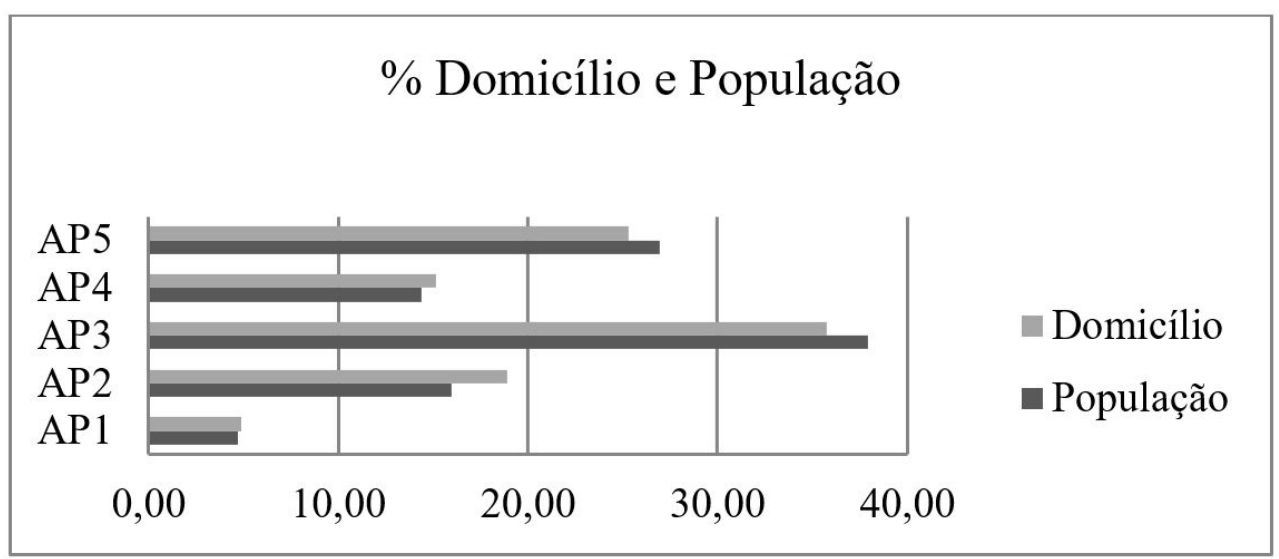

Figura 7 - Percentual de domicílios e população por área de planejamento ${ }^{2}$

Fonte: Gráfico elaborado a partir dos dados do IBGE (2011)

2 Percentual calculado por AP sobre o valor total de domicílios e população. 
Evidenciam-se também as áreas ocupadas por favelas e loteamentos irregulares. No tocante à proporção da população residente em favelas, em comparação ao restante da população, a AP3 apresenta o maior índice de residentes nos assentamentos precários em relação ao total da Cidade - 45\% (Tabela 1).

\section{Problema e Objetivo}

Nos últimos 15 anos, grandes transformações territoriais e sociais têm ocorrido na cidade do Rio de Janeiro, em consequência da realização de megaeventos culturais e esportivos, como os Jogos Pan-americanos em 2007, a Jornada Mundial da Juventude em 2013, a Copa do Mundo de Futebol em 2014 e os Jogos Olímpicos em 2016. Nesse contexto, significativas reformulações urbanísticas e arquitetônicas, como a implantação dos corredores expressos de ônibus, foram responsáveis por transformar a paisagem da região suburbana ferroviária (AP3), sem, contudo, levar em consideração de forma sistemática as consequências de tais transformações e os anseios da população local. O espaço livre urbano vem sendo relegado ao tratamento de questões ligadas à circulação de veículos e pedestres, comprometendo o caráter social e ambiental desse espaço, desenvolvendo uma paisagem desprovida de identidade (SILVA, 2004 apud TANGARI et al., 2009, p. 21).
Destaca-se ainda que a partir de premissas da legislação urbanística definida pelo Macrozoneamento do Plano Diretor da $\mathrm{Ci}$ dade do Rio de Janeiro, aprovado em 2011, a AP3 foi definida como Macrozona Incentivada, onde há incentivos por parte do Poder Público Municipal para verticalização. Estima-se que essa transformação morfológica do tecido urbano se dará mediante a substituição de tipos construtivos de residências unifamiliares de um a dois pavimentos e que possuem quintais ou jardins arborizados, por edificações multifamiliares acima de três pavimentos, que serão por sua vez implantadas em lotes onde os espaços livres residuais podem ser gradativamente substituídos por áreas pavimentadas para estacionamentos e áreas de lazer comum aos empreendimentos. Embasado por estudos anteriores que comprovaram alterações de microclima urbano, impulsionadas pela mudança de legislação urbanística (BUENO et al., 2012; MONTEZUMA et al., 2014; TÂNGARI; CARDEMAN, 2016), prevê-se o mesmo efeito para a AP3, acentuando o agravamento das condições microclimáticas referentes ao aumento de temperaturas e diminuição da umidade, além da criação de novas superfícies impermeabilizadas, já excessivas nessa região.

Tendo em vista a deficiência de estudos que retratem e abordem de forma qualitativa e quantitativa o tema dos espaços livres e a presença da arborização nesse território, este artigo busca apre-

Tabela 1 - População residente em favelas na Cidade do Rio de Janeiro. Destaque para a AP3.

\begin{tabular}{l|r|r|r|r|}
\hline \multirow{2}{*}{\multicolumn{1}{c|}{ Áreas de Planejamento }} & \multicolumn{3}{c}{ População Residente } \\
\cline { 2 - 5 } & Cidade & Proporção & Favela & Proporção \\
\cline { 2 - 5 } & 6.320 .446 & $100 \%$ & 1.443 .773 & $100 \%$ \\
\hline Total & 297.976 & $5 \%$ & 103.296 & $7 \%$ \\
AP1 - Central & 1.009 .170 & $16 \%$ & 174.149 & $12 \%$ \\
AP2 - Zona Sul & 2.399 .159 & $38 \%$ & 654.755 & $45 \%$ \\
\hline AP3 - Zona Norte & 909.368 & $14 \%$ & 236.834 & $16 \%$ \\
\hline AP4 - Barra/Jacarepaguá & 1.704 .773 & $27 \%$ & 274.739 & $19 \%$ \\
\hline AP5 - Zona Oeste & & & & \\
\hline
\end{tabular}

Fonte: IBGE, 2011 
sentar a análise multi-métodos de identificação, quantificação e categorização dos espaços livres e da arborização existentes no subúrbio ferroviário na cidade do Rio de Janeiro.

\section{Os espaços LiVRes}

Os espaços livres (EL) urbanos se destacam na paisagem da cidade e possuem extrema relação com a qualidade de vida e a dinâmica de ocupação do território. Segundo Tângari (1999, p. 184), "ao se formar através da ação de agentes públicos e privados, a cidade conjuga espaços construídos e espaços livres de edificação [...] tanto os espaços construídos quanto os livres de edificação conferem caráter e qualificam a paisagem das cidades." Queiroga e Benfatti (2007, p. 86) complementam a conceituação dos espaços livres como sistemas, ressaltando o caráter de conectividade e complementaridade mesmo que não tenham sido pensados como tal:
Os espaços livres urbanos constituem um sistema complexo, dada a inter-relação com outros sistemas urbanos que podem se justapor ao sistema de espaços livres (sistema de objetos edificados e seu correspondente sistema de ações) ou se sobrepor, total ou parcialmente, enquanto sistemas de ações. Neste último caso, interessa particularmente investigar as principais inter-relações entre o sistema de espaços livres e o sistema de espacialidades públicas nas áreas urbanas brasileiras, em que medida os sistemas de espaços livres contribuem para a produção da esfera pública contemporânea.

Podemos ilustrar os mais comuns espaços livres do meio urbano, conforme definido por Magnoli (1982), como: quintais, jardins públicos ou privados, ruas, avenidas, praças, parques, rios, florestas, mangues e praias urbanas, ou simples vazios urbanos, que constituem um sistema complexo com categorias e tipos que variam em quantidade e qualidade dependendo do setor urbano em que se localizam em cada cidade.

No tocante à cidade do Rio de Janeiro e, mais precisamente, à região do subúrbio ferroviário, torna-se evidente a carência de es- paços livres, principalmente os de caráter público (representados por praças, parques e espaços de lazer e recreação em geral), por consequência principalmente do alto índice de ocupação e privatização do solo (Figura 8). Ainda em 1999, em sua pesquisa de doutorado, Tângari constatou que apenas $8 \%$ do total de espaços livres públicos oficiais da cidade do Rio de Janeiro localizavam-se na zona norte da cidade, e sua superfície era inferior a 100 ha, dimensão essa que nas regiões centrais e sul aproximava-se de 1.000 ha (TÂNGARI, 1999). Atualmente, o percentual de distribuição de espaços livres públicos na AP3 é de $36 \%$, em uma área de 20.350 ha, sendo inferior ao percentual encontrado na Área de Planejamento $1-37 \%$, a menor das áreas de planejamento da Cidade com aproximadamente 3.440 hectares (Figura 9).

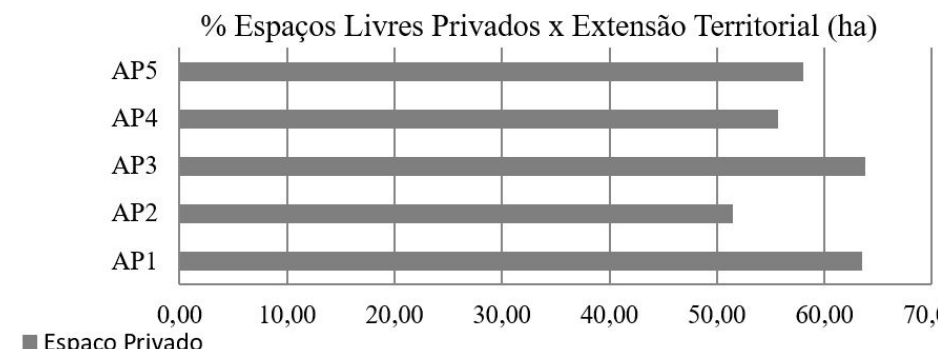

Figura 8 - Percentual de espaços livres privados por área de planejamento. Fonte: Sistemas de Espaços Livres no Rio de Janeiro (SEL-RJ), 2017.

\% Espaços Livres Públicos x Extensão territorial (ha)

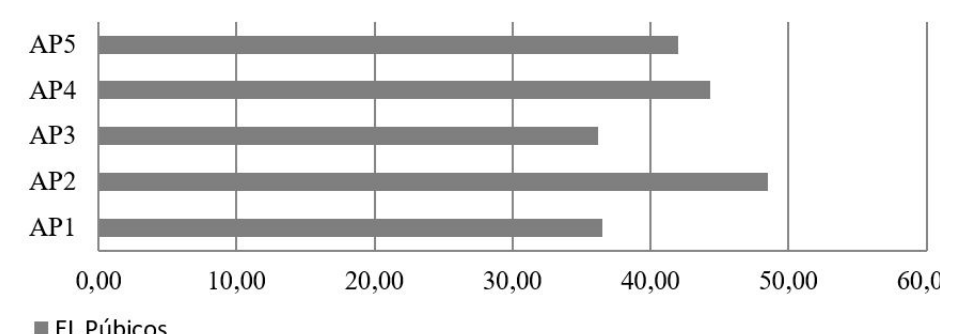

Figura 9 - Percentual de espaços Livres Públicos por área de planejamento. Fonte: Sistemas de Espaços Livres no Rio de Janeiro (SEL-RJ), 2017. 


\section{A Arborização Urbana}

O termo arborização define o ato ou efeito de arborizar, onde arborizar, por sua vez, representa a ação de plantar ou guarnecer com árvores e a palavra arborizado é entendida como espaço plantado ou cheio de árvores (FERREIRA, 2010). É ainda entendido como o resultado do plantio e manutenção de árvores, quer sejam individuais ou em grupos. Já a arborização urbana é compreendida como o conjunto de todas as árvores e vegetação associadas dentro de uma determinada área urbana, seja ela, um pequeno núcleo povoado ou uma grande metrópole (MILLER, 2015). Incluem-se nessa categoria a massa arbórea existente em ruas, avenidas, praças e parques; unidades de conservação e pre- servação, assim como em áreas privadas, remanescentes de ecossistemas naturais ou plantadas.

O papel desempenhado pela arborização, na configuração dos espaços urbanos, é sem dúvida um ponto de grande importância. Inicialmente, questões estéticas e relacionadas ao embelezamento se tornaram mais frequentes com a inclusão consciente da arborização nas áreas urbanas, na Europa do século XVII (PITT et al, 1979 apud FARAH, 1997). Os estilos que marcaram a história de projetos de espaços livres, o francês no século XVII e o inglês no século XVIII, foram influência direta não apenas à forma de inserção do elemento arbóreo nas cidades como também para a concepção dos espaços livres, principalmente a partir do século

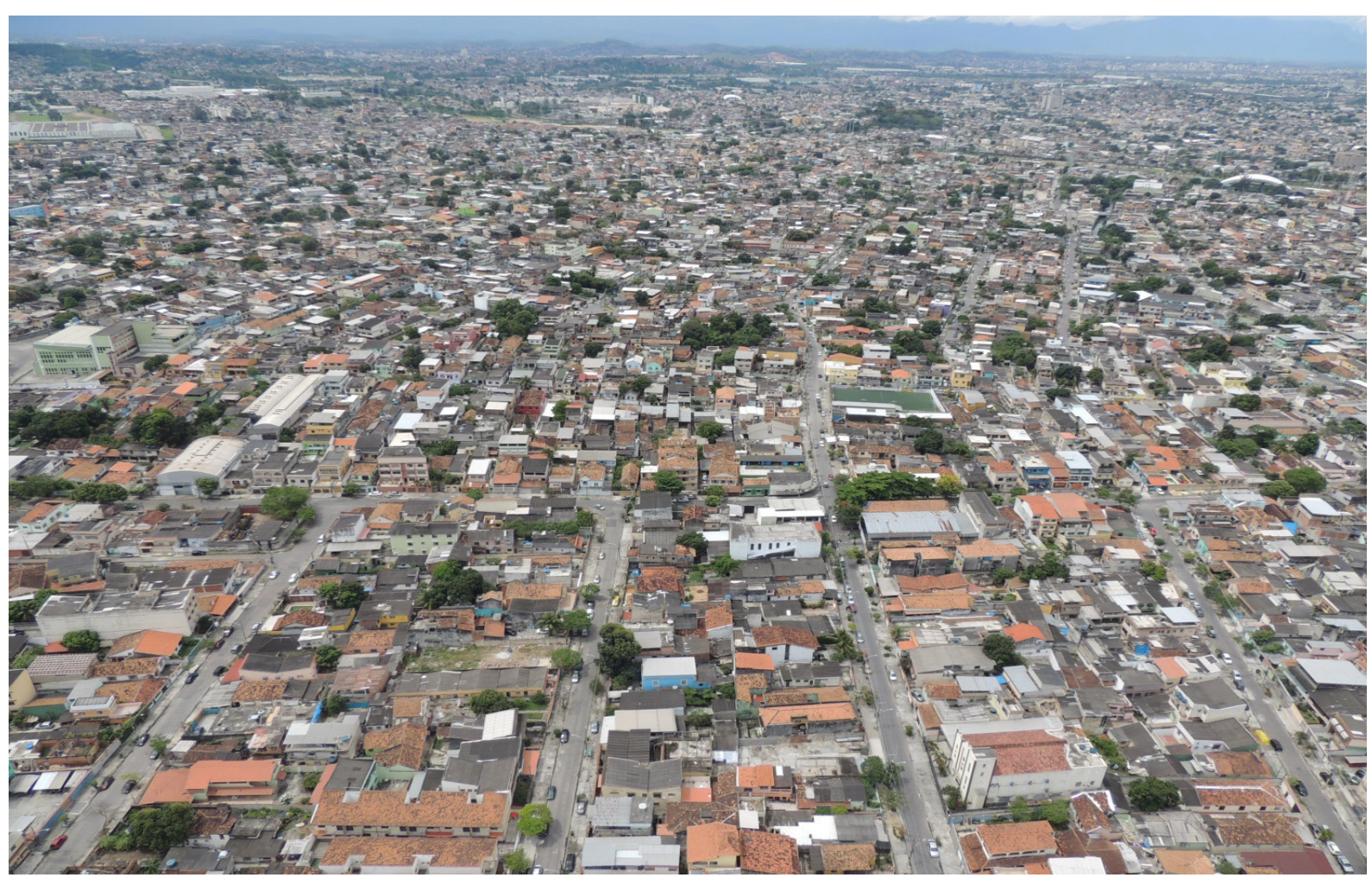

Figura 10 - Elevada impermeabilização do solo e ausência de arborização em trecho de bairro da AP3.

Fonte: Acervo do SEL-RJ, 2017. 
XVIII, ressaltando a ligação entre o paisagismo e o desenho urbano (KOSTOF, 1991).

Entretanto, a verdadeira função do elemento arbóreo vai além das questões estéticas originadas no século XVII ou das políticas higienistas do século XIX, que destacavam a importância do elemento arbóreo, sendo este responsável principalmente pela oxigenação do ar nas cidades. Diversos autores atestam a importância do elemento vegetal em meio urbano, em seus âmbitos geo-biofísico, cultural e ambiental, conforme publicação recente sobre o papel da vegetação nativa no planejamento e projeto paisagístico (BARRA et al, 2015). A partir de meados do século XIX a importância da presença da arborização nas cidades passou a ser ressaltada por vários profissionais e teóricos do urbanismo e paisagismo, como Sitte (1900 apud COLLINS; COLLINS, 2006), Lynch (1972) e Cullen (1999), que buscaram retratar não apenas os benefícios estéticos da arborização, mas também questões simbólicas, psicológicas e emocionais relacionadas às contribuições naturais na paisagem urbana.

Nesse contexto, observando-se as questões climáticas e geo-biofísicas da região dos subúrbios a noroeste da cidade do Rio de Janeiro, cujas médias de temperatura máxima atingem, no verão, cerca de $32,6^{\circ} \mathrm{C}^{3}$, o elemento vegetal ganha destaque, juntamente com demais elementos morfológicos do espaço urbano, pela sua baixa incidência (Figura 10).

\section{5. Área de Estudo e Métodos}

Tendo em vista a complexidade do território suburbano ferroviário e seu extenso limite geográfico, a pesquisa em tela limitou o recorte de análise apenas aos bairros inclusos no limite geográfico da AP3 e que apresentam características de uma ocupação mais consolidada, originalmente atravessados pela EFCB, conforme ilustrado na Figura 11. A área de estudo selecionada

\footnotetext{
3 Média de temperaturas máximas registradas entre o período de 20/12/2017 e 20/03/2018. Dados coletados na estação de Realengo/Rio de Janeiro-RJ. Fonte: Dados da Rede do Instituto Nacional de Meteorologia (Inmet). Disponível em http://tempo.inmet.gov.br/Graficos/83801. Acesso em: 10 mar. 2020
}

para a pesquisa é atravessada por aproximadamente $17 \mathrm{~km}$ da linha férrea Central do Brasil, e subdivide-se em 16 bairros. São eles os bairros de Marechal Hermes, Bento Ribeiro, Osvaldo Cruz, Madureira, Cascadura, Quintino, Piedade, Encantado, Engenho de Dentro, Todos os Santos, Meier, Engenho Novo Sampaio, Riachuelo, Rocha e São Francisco Xavier.

O estudo toma como base a metodologia utilizada pela Rede Nacional de Pesquisa Quadro do Paisagismo do Brasil - Sistema de Espaços Livres (QUAPÁ-SEL )e pelo Laboratório Sistemas de Espaços Livres no Rio de Janeiro (SEL-RJ), vinculado ao Programa de Pós-Graduação em Arquitetura da Universidade Federal do Rio de Janeiro (PROARQ-UFRJ) para a identificação, e caracterização dos sistemas de espaços livres (CAMPOS et al, 2011, 2012). Levaram-se em consideração para a escolha da metodologia a ser utilizada a qualidade dos estudos desenvolvidos sobre o tema dos espaços livres pelos grupos de pesquisa destacados, assim como, o farto material de pesquisa produzido e disponibilizado para consulta, pela Prefeitura da Cidade do Rio de Janeiro.

Para a análise dos espaços livres públicos e privados na cidade do Rio Janeiro, a pesquisa utilizou como referência o mapeamento realizado pelo Grupo SEL-RJ onde foram identificados e classificados os espaços livres públicos e privados conforme categorização pré-determinada (TÂNGARI, 2018).

No mapeamento dos espaços livres privados, levou-se em consideração o percentual de incidência da ocupação da superfície das quadras, sendo dessa forma estabelecidos os padrões de ocupação e incidência de espaços livres privados: "até 30\%", "de 30\% a 50\%" e "acima de 50\%" de espaços livres de edificação nas quadras. Já para a identificação dos espaços livres de caráter público, tomou-se como referência a categorização dos espaços livres e seus respectivos tipos:

Categoria: espaço livre de caráter ambiental, onde também podem ocorrer atividades de lazer e recreação:

- Unidade de conservação - Figura de lei que corresponde, nesta pesquisa, às áreas abrangidas pelas serras, delimitadas conforme decreto, e os Maciços da Tijuca, Pedra Branca e Gericinó; 


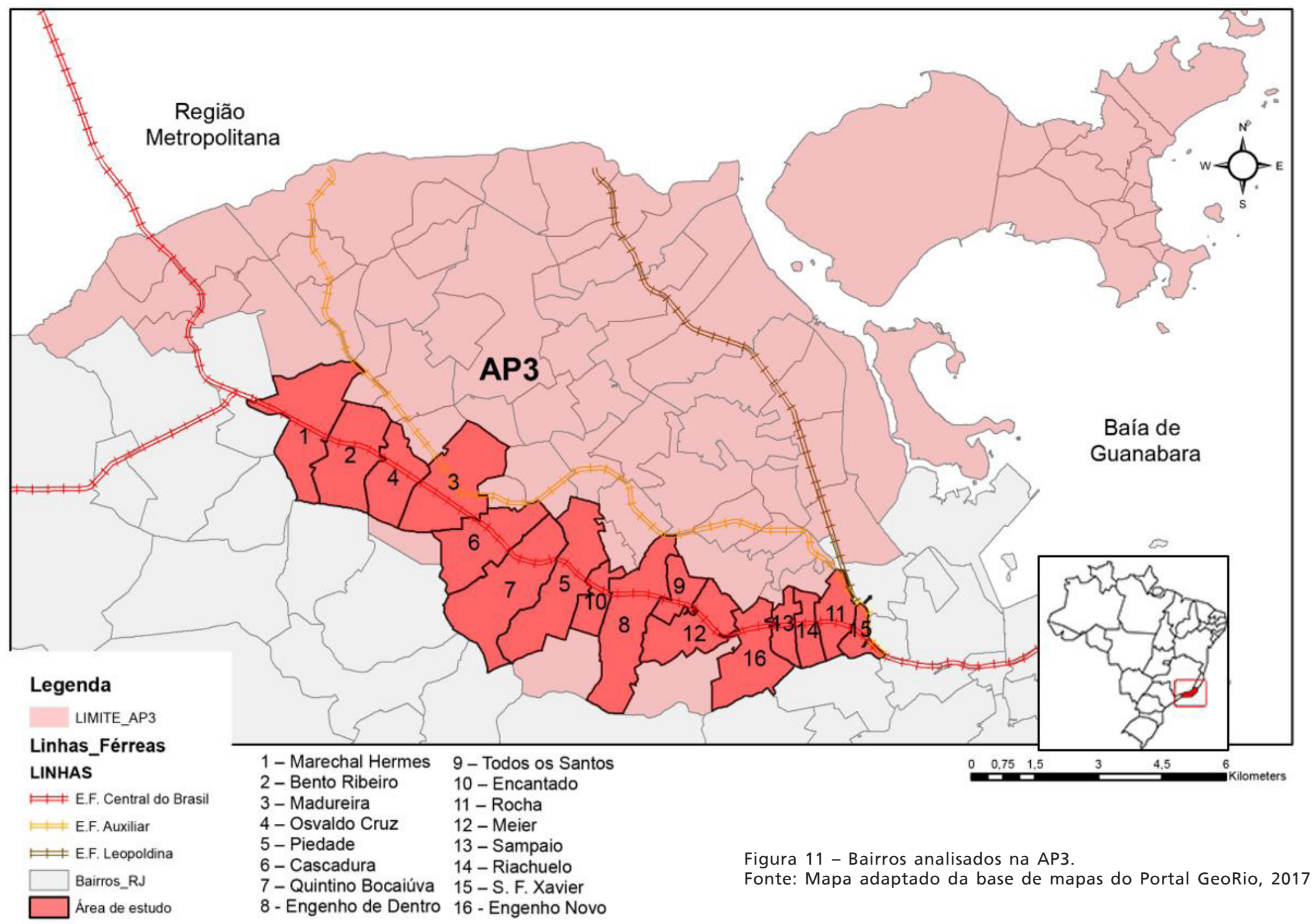

- Orla - Zona Costeira Continental, correspondente a espaço livre de preservação permanente adjacente a corpos hídricos com vegetação, areia, pedra e afins. Inclui praias e demais faixas marginais;
Categoria: espaço livre de caráter urbano, relacionado à circulação de veículos ou pedestres, onde também podem ocorrer atividades de recreação, comércio, esportes, cultura, educação, ações políticas e festividades: 
- Acostamento - Área de refúgio lateral localizada na faixa de domínio de uma rodovia ou via urbana;

- Calçadão - Calçada desenhada com projeto específico ou proveniente de alterações significativas com dimensões acima dos padrões;

- Canteiros - viário, central, lateral ou residual de acerto viário localizada nas vias ou junta a vias públicas, com ou sem vegetação;

- Ciclovia - Via destinada à circulação exclusiva de bicicletas e veículos não motorizados e vedada a veículos motorizados;

- Deque - Superfície suspensa sobre um corpo hídrico, inclui cais e marinas;

- Estacionamento - Área pública de estacionamento de veículos - bolsão ou similar - não se refere a vagas de estacionamento nas vias;

- Passarela - Via elevada para circulação preferencial de pedestres e vedada a veículos motorizados;

- Rotatória - Ilha, geralmente em forma circular, cercada por vias para retorno e cruzamentos, com ou sem vegetação;

- Rua e avenida - Caixa de rolamento entre alinhamentos das edificações inclui, de forma geral, as calçadas laterais;

- Terminal rodoviário - Conjunto de baias de ônibus localizado fora da faixa de rolamento da rua com parada e abrigos para proteção de pedestres;

- Viaduto - Pista de veículos elevada marcada visualmente do início ao fim da rampa

- Rua de pedestre - Via destinada à circulação preferencial de pedestres e vedada a veículos motorizados;

Categoria: espaço livre de caráter urbano, relacionado à permanência de pedestres podendo ocorrer atividades de recreação, comércio, esportes, cultura, educação, ações políticas e festividades:

- Parque - Espaço livre público decretado, especialmente como parque;
- Praça - Área determinada em projeto de loteamento como espaço livre público para atividades recreativas;

- Praça não implantada - Área determinada em projeto de loteamento como espaço livre público para atividades recreativas e que não foi executada;

- Praça ocupada - Área determinada em projeto de loteamento como espaço livre público para atividades recreativas e que foi desmembrada (acima de $50 \%$ ) para construção de equipamento de saúde, educação ou residencial;

- Campo de futebol - Espaço livre informal isolado onde se joga bola;

Categoria: espaço livre de caráter urbano, relacionado à infraestrutura administrativa, de transportes, saneamento, educacional, cultural, onde também podem ocorrer atividades de comércio, serviços, recreação, esportes, cultura, educação:

- Espaço de uso especial/dominial - Espaços não edificados de propriedade pública e concedidos a usos especiais - ferrovias, portos, aeroportos, campos universitários, etc;

A avaliação da vegetação urbana com espécies arbóreas foi realizada a partir do mapeamento da massa arbórea existente, nos espaços livres de caráter público e privado. Tal mapeamento foi possível pelo uso do software ArcGis, a partir de imagem satélite (ortofoto), da Cidade do Rio de Janeiro, do ano de 2015 , disponibilizado pela Prefeitura da Cidade do Rio de Janeiro. A metodologia consistiu-se então, na identificação e mapeamento de manchas arbóreas evidentes no espaço urbano, a partir das imagens em escala pré-determinada de 1:2.000, conforme exemplificam as Figuras 12 e 13. Posteriormente, trabalhos de campo complementaram a análise das manchas de difícil detecção.

Torna-se importante esclarecer que a vegetação arbórea não está presente apenas nas áreas demarcadas no estudo, porém, a vegetação existente, que se torna irrelevante em relação à escala determinada, foi desconsiderada. Não foram avaliadas na pesquisa as manchas arbóreas em cotas elevadas, onde a ocu- 

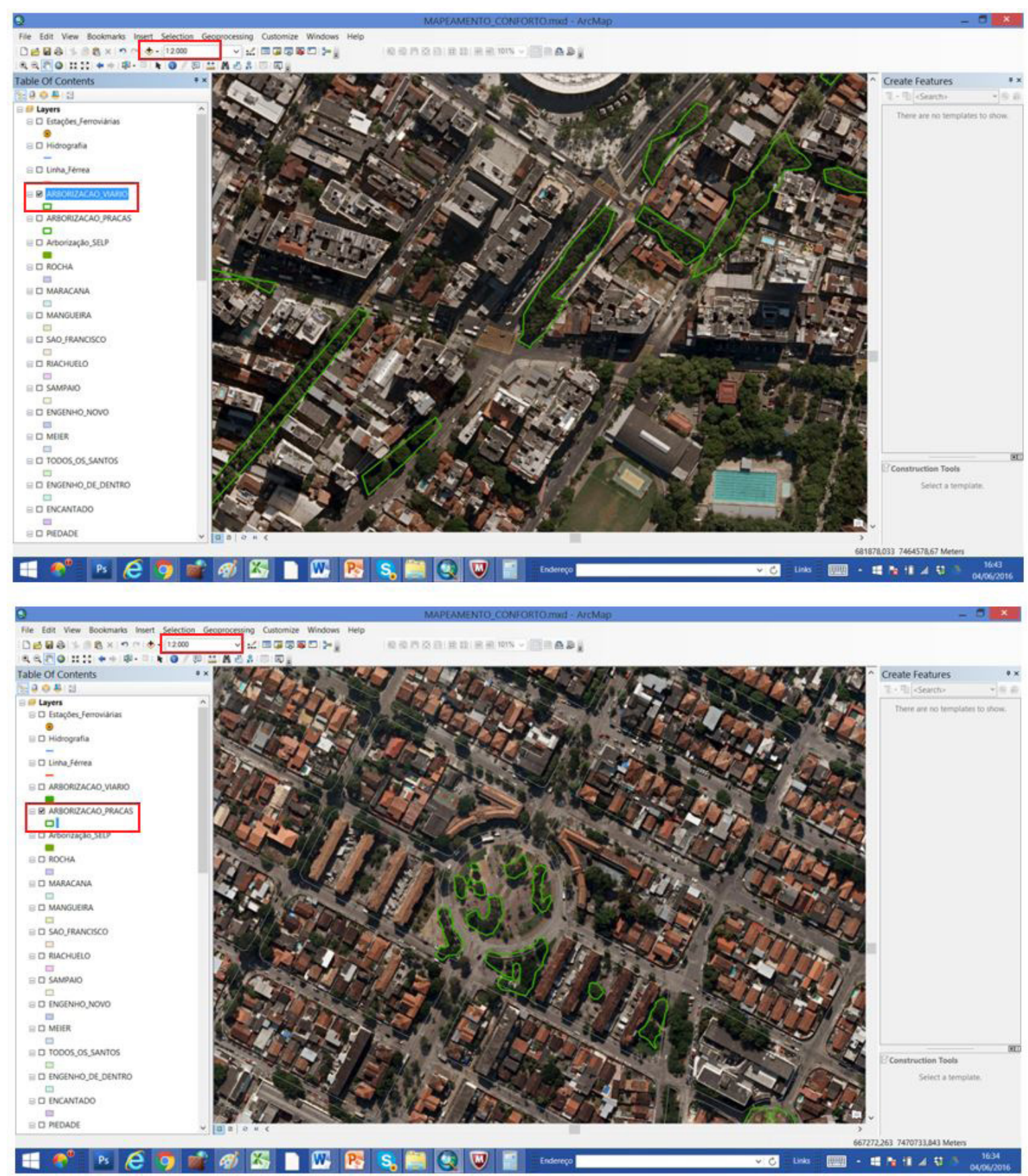

Figuras 12 e 13 - Visualização da tela de trabalho do software ARCGIS 10.3. com destaque para a marcação da massa arbórea. 
pação é por muitas vezes inviável do ponto de vista estrutural e ambiental ou proibida pela legislação, e as manchas existentes em assentamentos residenciais irregulares, representados por favelas e loteamentos irregulares, por entender que esses territórios apresentam uma conformação peculiar e singular de ocupação do solo e que merecem estudo específico. Cabe também ressaltar, que são aqui consideradas as definições de propriedades públicas e privadas especificadas no Código Civil brasileiro vigente, desde 2003, onde se classificam as propriedades privadas como aquelas estritamente de uso privado e as propriedades públicas divididas em: de uso comum do povo (praças, ruas, parques, praias, etc.), de uso especial (as propriedades de uso específico dos entes públicos como Exército, escolas públicas, hospitais públicos, etc.) e dominicais ou dominiais (propriedades públicas alienáveis sem desafetação, pois não apresentam nenhuma destinação pública).

Apesar de tomar como base as definições de propriedade acima citadas, para a análise em questão entende-se que os espaços livres das propriedades de uso especial e dominiais apresentam restrições de acesso à população e por esse motivo a vegetação presente nesses ambientes atua de forma indireta ao meio em que está inserida de maneira similar à vegetação presente nos espaços privados. Por esse motivo e, em particular, na avaliação da mancha arbórea distingue-se aqui a vegetação presente nos espaços públicos de uso comum do restante da massa arbórea pertencente aos demais espaços privados ou semiprivados.

\section{Resultados e Discussão}

\subsection{Espaços LiVRes PRIVAdos}

Conforme pode ser observado no mapa representado pela Figura 14, a maior incidência de espaços livres nos bairros de Cascadura, Quintino e Engenho de Dentro é explicada pela existência de áreas residuais lindeiras ao Maciço da Tijuca. Em sua maioria, correspondem a áreas de acentuado declive e de altas cotas que são, em geral, restritas à ocupação através de decretos e leis ambientais (non aedificandi) ou em lotes pertencentes a equipamentos ou instituições privadas como colégios, ginásios e estádios. Já no Bairro de Marechal Hermes e no Rocha essa maior incidência explica-se pela presença de grandes áreas institucionais militares.

Na escala municipal, é interessante observar os dados representativos dos espaços livres privados a partir de cada Região Administrativa (RA): através de uma análise comparativa entre as áreas de planejamento, apresentada na Figura 15, torna-se claro o reduzido percentual de espaços livres de caráter privado na região da AP3, caracterizado em sua maioria por uma incidência de até $30 \%$ de espaços livres intra-quadras, o que também ressalta a elevada densidade de área construída no subúrbio (Figuras 16 e 17).

Devido à complexidade e à escala de análise, não foi possível efetuar o detalhamento e a quantificação dos espaços livres privados lote a lote. Considerou-se no estudo apenas a incidência desses espaços em uma análise quadra a quadra, determinando o percentual de espaços livres observados na superfície das quadras.

Entretanto, a partir da quantificação total das quadras urbanas é possível estabelecer relação entre a extensão de cada área de planejamento e a área total dos espaços livres privados entendendo os espaços privados como superfícies que englobam áreas edificadas e não edificadas. O resultado se torna relevante, pois comprova o alto índice de ocupação do solo na região do subúrbio ferroviário em sua grande maioria pertencente à AP3, onde aproximadamente $64 \%$ do território compõem-se de terrenos ocupados, sendo o maior índice de ocupação por área de planejamento.

$\mathrm{Na}$ análise individualizada das Regiões Administrativas de Méier e Madureira os valores de ocupação do solo são ainda maiores conforme demonstra a Figura 18. 


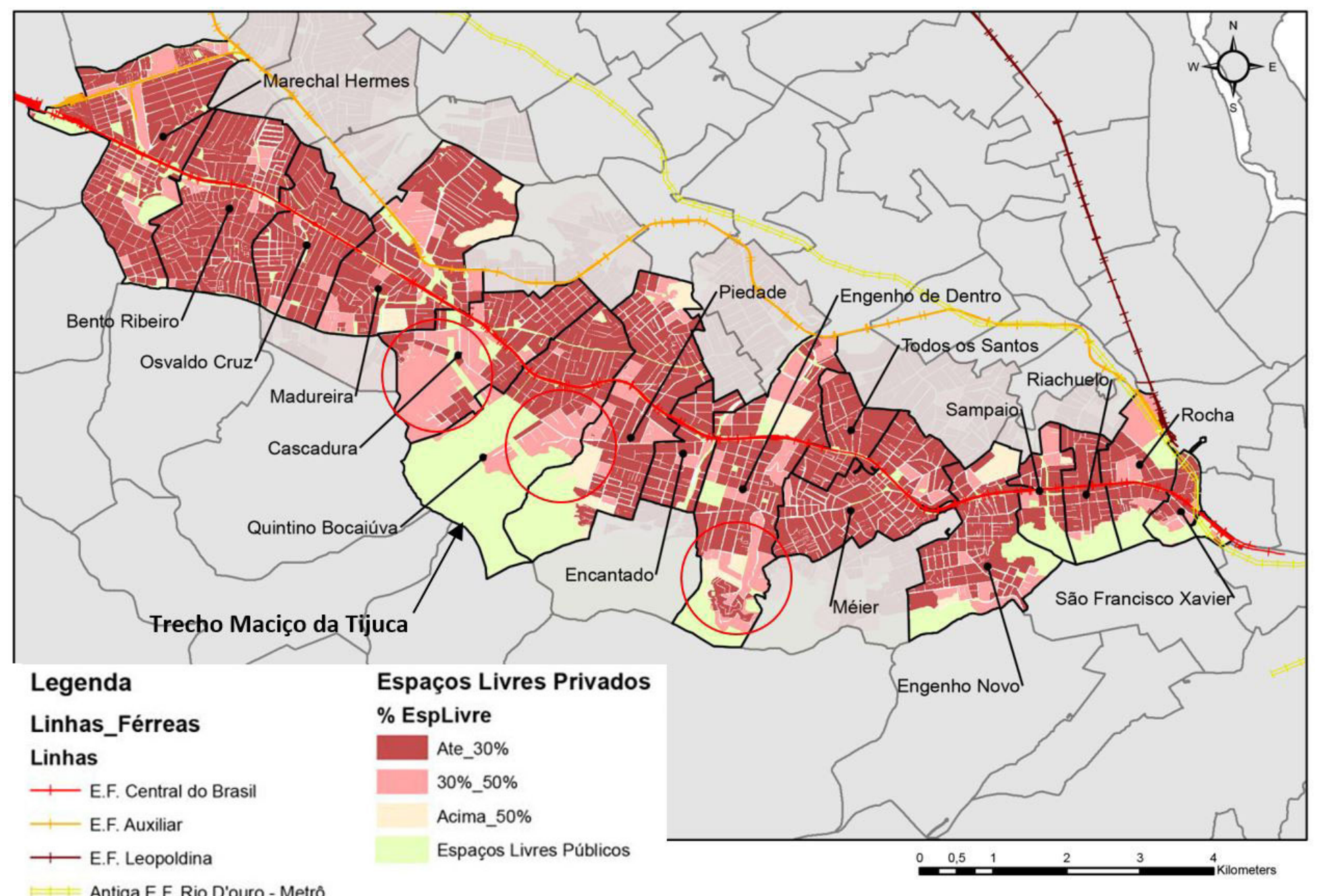

Figura 14 - Análise de espaços livres privados por quadras. Fonte: Mapa adaptado da base de dados SEL-RJ, 2017. 
Espaços Livres Privados (Hectare) x Área de Planejamento

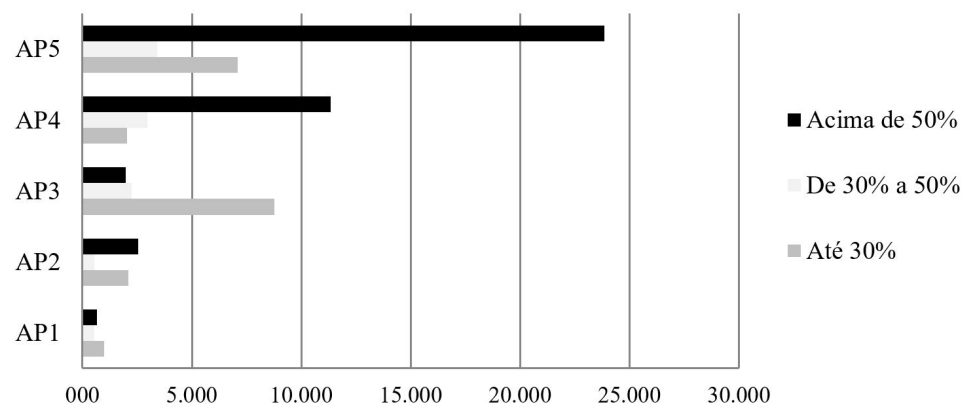

Figura 15 - Mapeamento dos espaços livres privados por RA. Fonte: SEL-RJ, 2017.

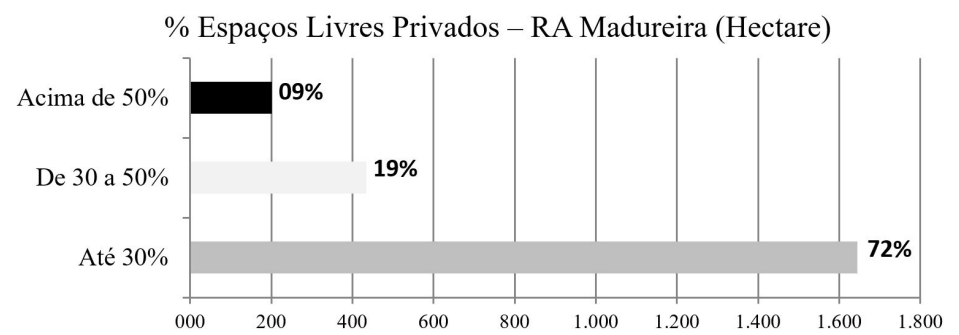

Figura 16 - Percentual de espaços livres privados por quadras na RA Madureira.

Fonte: SEL-RJ, 2017

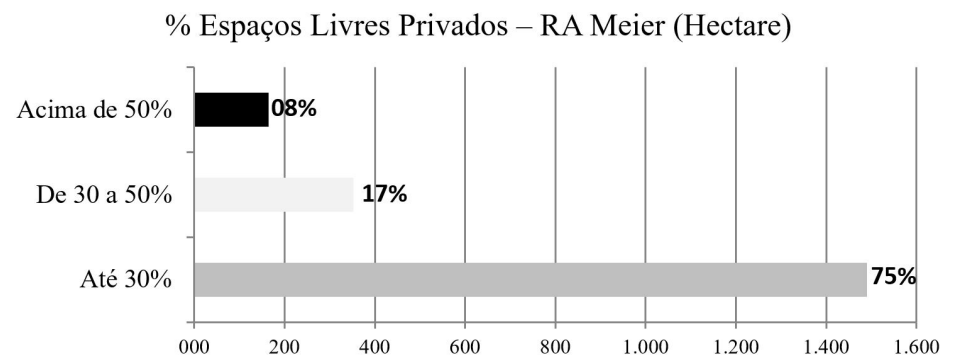

Figura 17 - Percentual de espaços livres privados por quadras na RA Meier.

Fonte: SEL-RJ, 2017
\% Espaços Livres Privados x Ext. Territorial

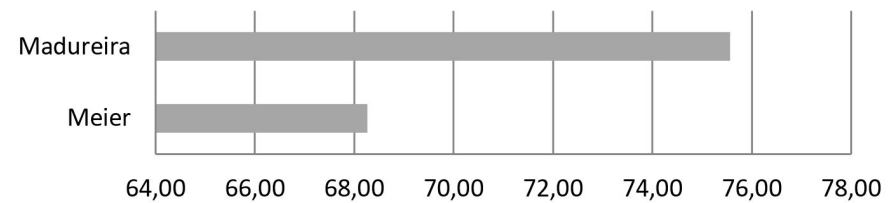

\section{Espaço Privado}

Figura 18 - Espaços Privados por RA. Fonte: SEL-RJ, 2017

\subsection{Espaços Livres Públicos}

Em relação à superfície ocupada, os mais representativos espaços livres públicos incluem: os espaços destinados à circulação de veículos ou pedestres, formados por ruas e avenidas; espaços livres de caráter ambiental, em sua maioria sem acesso ao público ou de acesso restrito devido à ocupação irregular de favelas e loteamentos informais e espaços de uso dominial cedidos às forças militares ou concessionárias de serviços (iluminação, abastecimento de água, transporte ferroviário, etc) (Figura 19). Observa-se que a área total de espaços livres é diretamente proporcional à extensão das áreas de planejamento: quanto maior a AP, maior a área de espaços livres públicos ofertada (Figura 20). Entretanto, quando se considera a relação entre espaços livres e a extensão territorial das áreas de planejamento, a AP3 apresenta o menor índice de distribuição de espaços livres por hectare da Cidade (Figura 21).

\subsubsection{O CASO DAS PRAÇAS NO SUBÚRBIO}

A avaliação individualizada dos espaços públicos representados por praças, no subúrbio, revela uma questão particular e que merece destaque no material aqui apresentado: tais locais já escassos nessa região, ainda são por vezes suprimidos, para a implantação de equipamentos de educação e saúde. A prática 


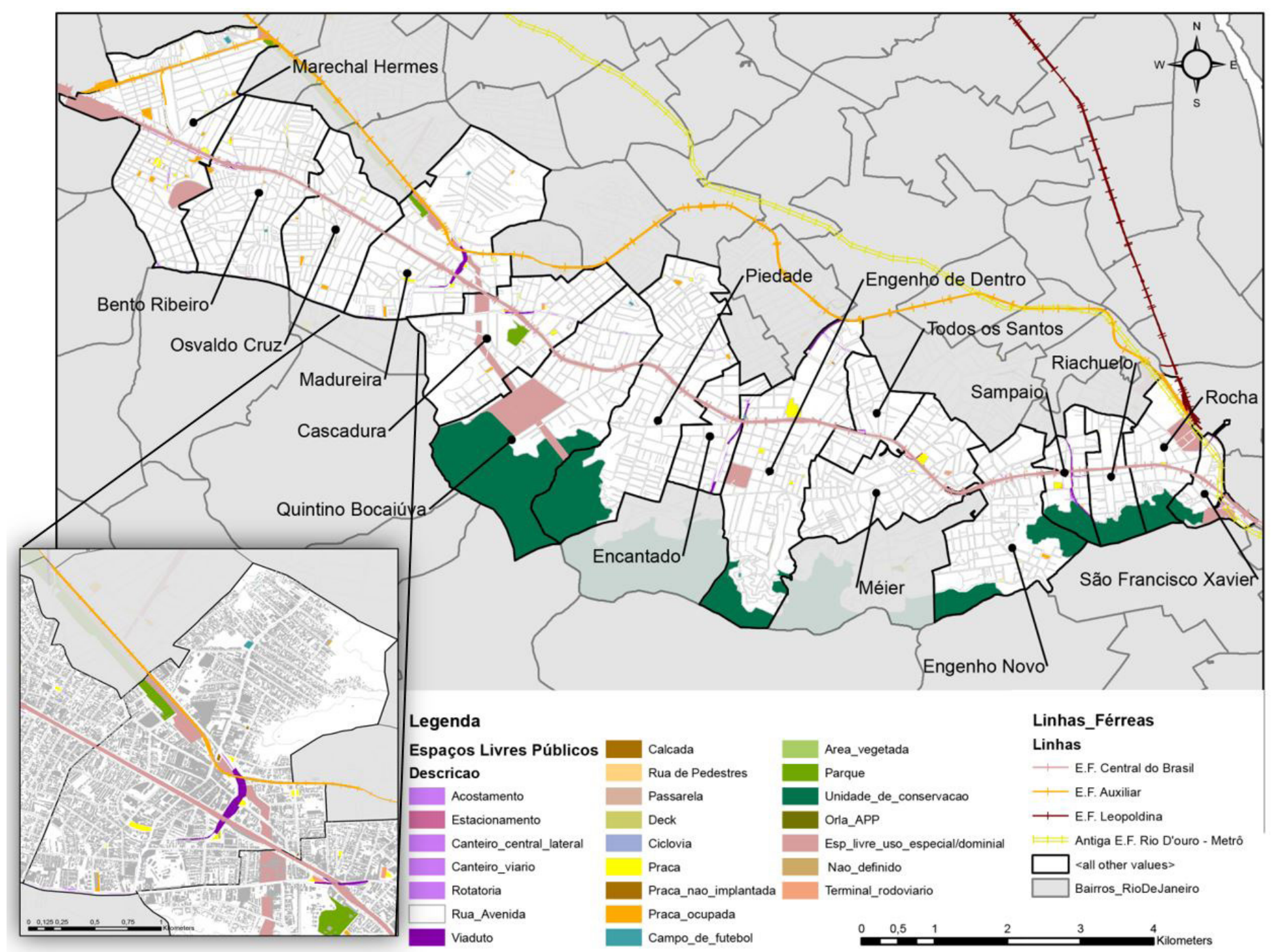

Figura 19 - Análise de espaços livres públicos com ampliação do bairro de Madureira. Fonte: Mapa adaptado da base de dados SEL-RJ, 2017. 
Espaços Livres Públicos(Ha) por AP

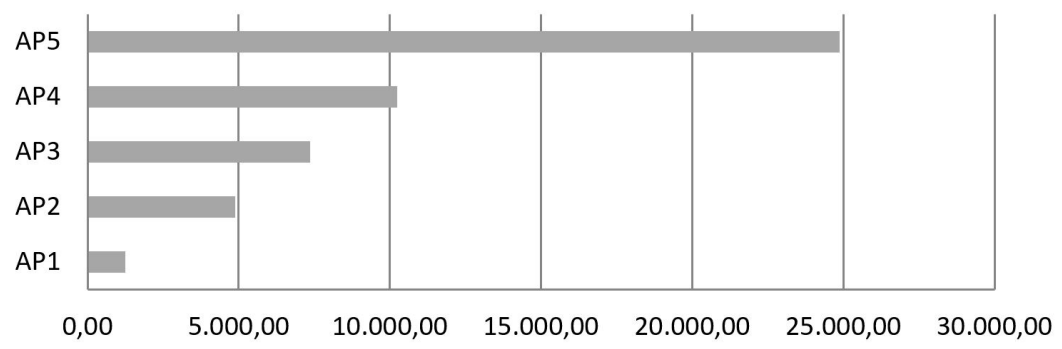

EL Púbicos

Figura 20 - Espaços Livres Públicos por Área de Planejamento. Fonte: SEL-RJ, 2017.

de ocupar espaços livres públicos destinados ao lazer para a implantação de outros serviços essenciais não é recente na história da Cidade. Ainda em 1960, na eleição da primeira gestão do recém-criado Estado da Guanabara, Carlos Lacerda promoveu sua candidatura com a promessa de acabar com o déficit de vagas nas escolas primárias do Estado. Até o fim daquele ano, 78 escolas foram inauguradas e muitas delas situadas na região dos subúrbios do Rio de Janeiro. Entre os anos de 1960 e 1965 cerca de 200 escolas primárias foram construídas (PEREZ, 2005). Duas importantes premissas foram adotadas nessa época pelo governo para agilizar o processo de construção das escolas e reduzir os custos de implantação: a primeira estabeleceu um padrão arquitetônico baseado na padronização dos materiais utilizados e a segunda foi a implantação dos edifícios em praças públicas (Figura 22).

Através de manobra jurídica implantada por meio de decreto e respaldada no Código Civil Brasileiro, a administração pública pode utilizar o bem de uso comum do povo para atender a necessidade do próprio ente. Segundo esses decretos, a praça deixa
\% Espaços Livres Públicos(Ha) x Extensão territorial

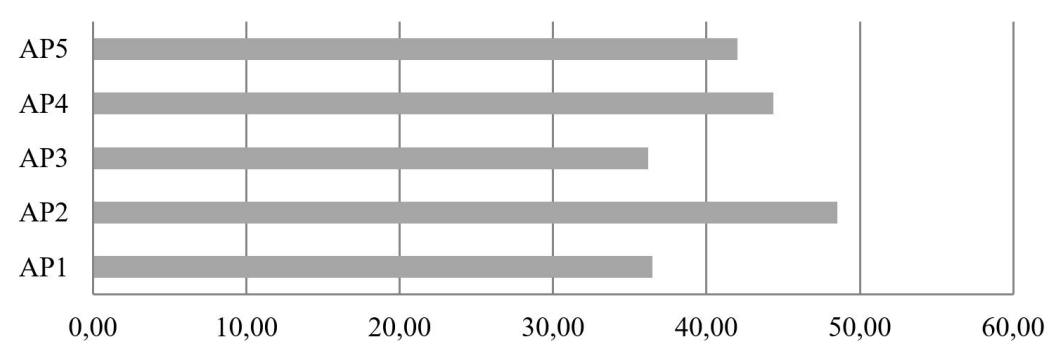

EL Púbicos

Figura 21 - Percentual de espaços Livres Públicos x Extensão territorial da AP. Fonte: SEL-RJ, 2017.

de pertencer à categoria de "bem de uso comum" e passa a ser "bem de uso especial" passível de desafetação ou alteração de afetação, legitimando a implantação de edificação pública em área destituída de praça. A alteração pode ser parcial ou total. Em muitos casos observados, as informações contidas na base de dados da própria Prefeitura da Cidade do Rio de Janeiro são conflitantes e não correspondem à realidade: apesar de ser classificado como praça pública, o lote possuí toda sua área ocupada por uma escola. Nesse caso específico, assim como em outros identificados, não foi possível localizar o decreto que legitimou o novo uso para o local.

Com base nesse histórico de supressão de praças, a pesquisa buscou realizar a compatibilização das áreas de praças e parques, assim como suas condições atuais, a partir da base de dados da Prefeitura da Cidade do Rio de Janeiro ${ }^{4}$. Das 114 praças identificadas no recorte de estudo, apenas $58(51 \%)$ foram identificadas

4 Arquivo em formato shapefile (.shp) referente a demarcação em mapa dos usos do solo na cidade do Rio de Janeiro no ano de 2017. Disponível através do link https://bit.ly/3boJYJ0. Acesso em: 18 mar. 2020 


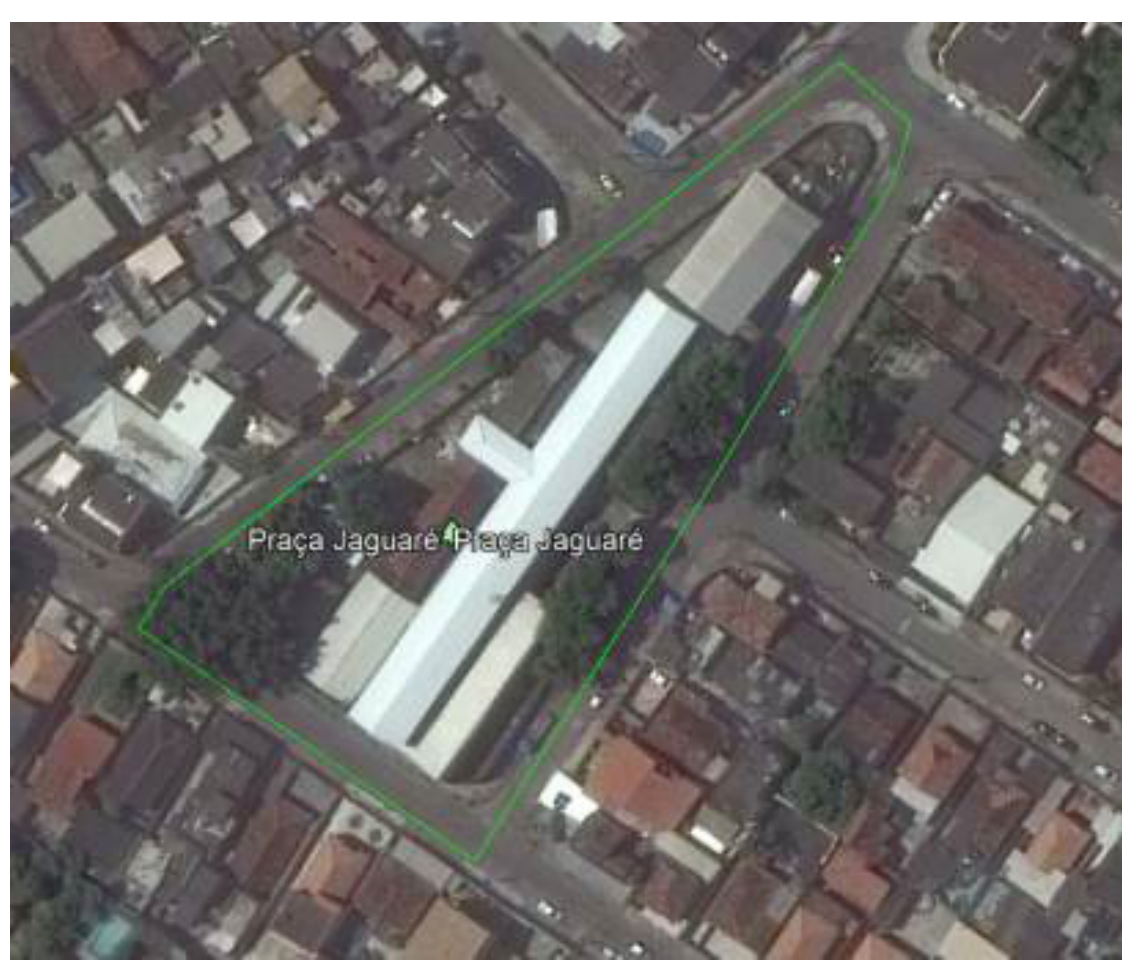

Figura 22 - Escola instalada em antiga área de praça no Bairro de Osvaldo Cruz.

Fonte: Google Earth, 2017. e podem ser de fato caracterizadas como praças ou parques. Do restante, $13(12 \%)$ são decretadas como praça segundo o levantamento, porém, através da alteração de afetação parcial ou total do espaço público, são ocupadas em sua maioria, por escolas ou clínicas públicas. As 43 restantes (37\%) são áreas indicadas como sendo praças, porém são na realidade espaços livres privatizados (apropriação indevida do espaço público), ou espaços livres que deixaram de existir devido a mudanças viárias e redesenho de traçados urbanos em geral.

O levantamento realizado deu origem ao mapa representado pela Figura 23 e ao gráfico da Figura 24 que elucidam as informações prestadas.
Os Bairros de Madureira e Marechal Hermes se destacam como os bairros com o maior número de praças. Marechal Hermes também apresenta o maior número de praças inexistentes, onde muitos espaços demarcados como praças são na realidade canteiros e estacionamentos de condomínios residenciais. O Bairro do Engenho de Dentro também se destaca pelo número de praças inexistentes: as áreas demarcadas ao norte da ferrovia são atualmente terrenos ocupados por prédios residenciais, e ao sul os espaços demarcados incorretamente são grandes áreas ocupadas por habitações informais nas franjas do Maciço da Tijuca. Marechal Hermes ainda apresenta o maior número de praças ocupadas, juntamente com o bairro de Osvaldo Cruz. 


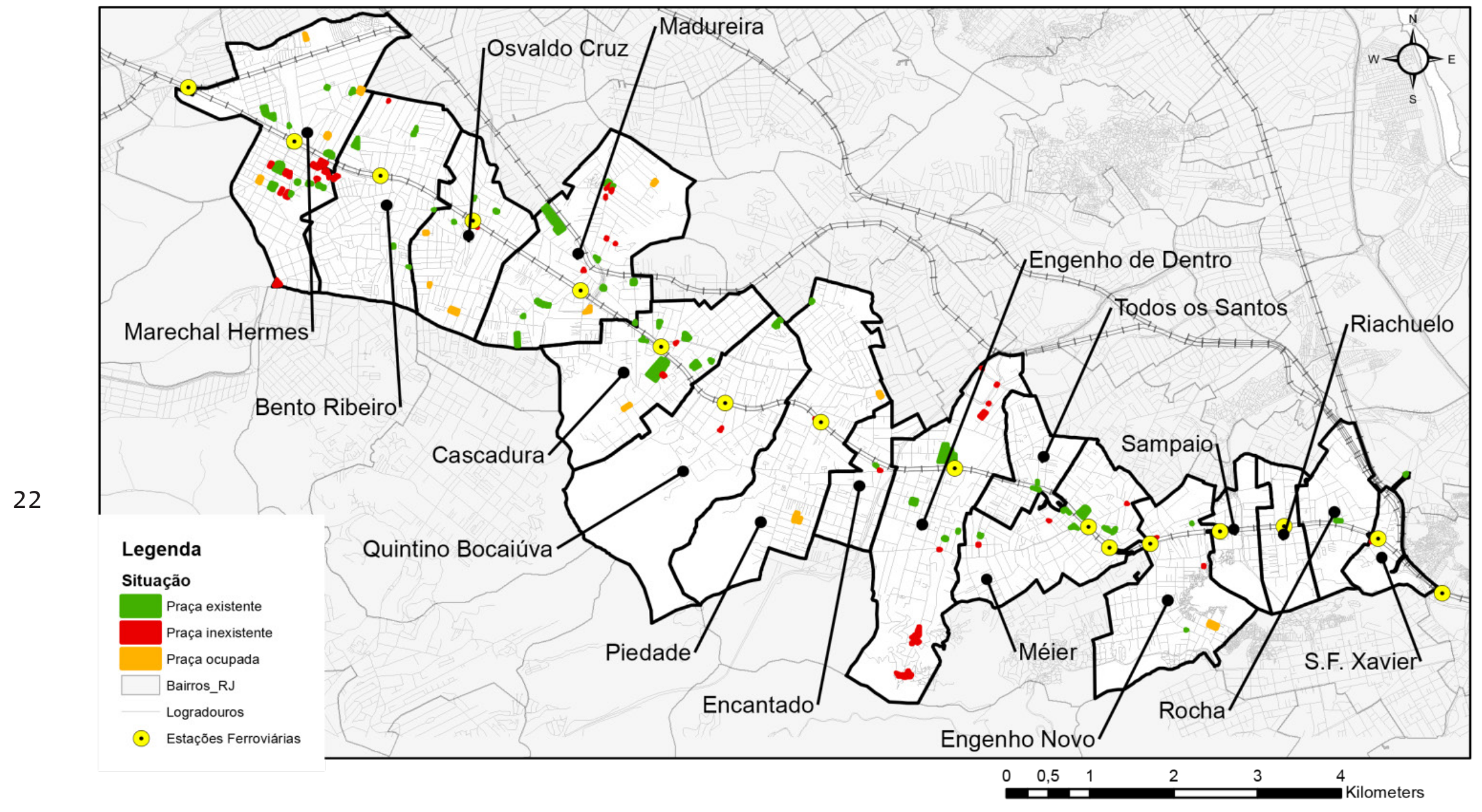

Figura 23 - Localização e análise de praças e parques. 


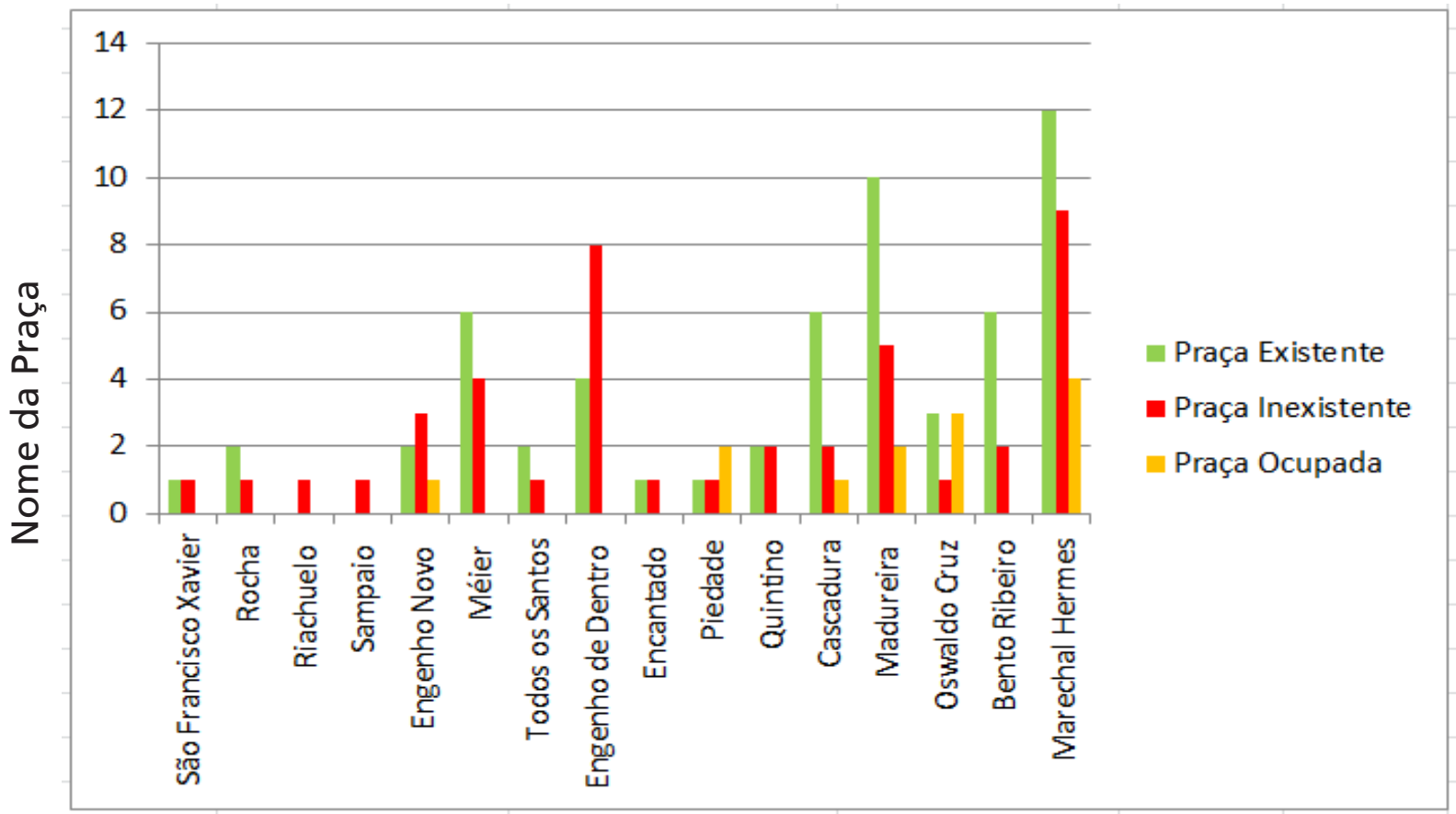

Figura 24 - Situação de praças e parques por bairro.

\subsection{ArborizaÇão}

Com base na metodologia proposta, foi possível a identificação e mapeamento da massa arbórea existente na área de estudo (Figura 25). A partir da comparação entre espaços públicos e privados pôde-se atestar que, esses últimos, compreendem $83 \%$ de toda a área arborizada considerada em contrapartida aos $17 \%$ incidentes nos espaços públicos (Tabela 2).

Conforme elucidado na tabela, o percentual da arborização dos espaços livres privados nos bairros avaliados se fez amplamente superior à existente nos espaços públicos (Figura 26). Além das áreas militares outros fatores são determinantes quanto à existência da massa arbórea em espaços privados:
- Significativa quantidade de terrenos privados que abrigam torres de transmissão de energia;

- Incorporação de áreas residuais adjacentes a corpos hídricos, aos lotes residenciais;

- Predominância de habitações unifamiliares com manutenção de quintais e áreas ajardinadas, responsáveis pela formação de corredores arbóreos nos fundo dos lotes;

- Boa arborização das áreas de uso comum de alguns conjuntos habitacionais multifamiliares; 


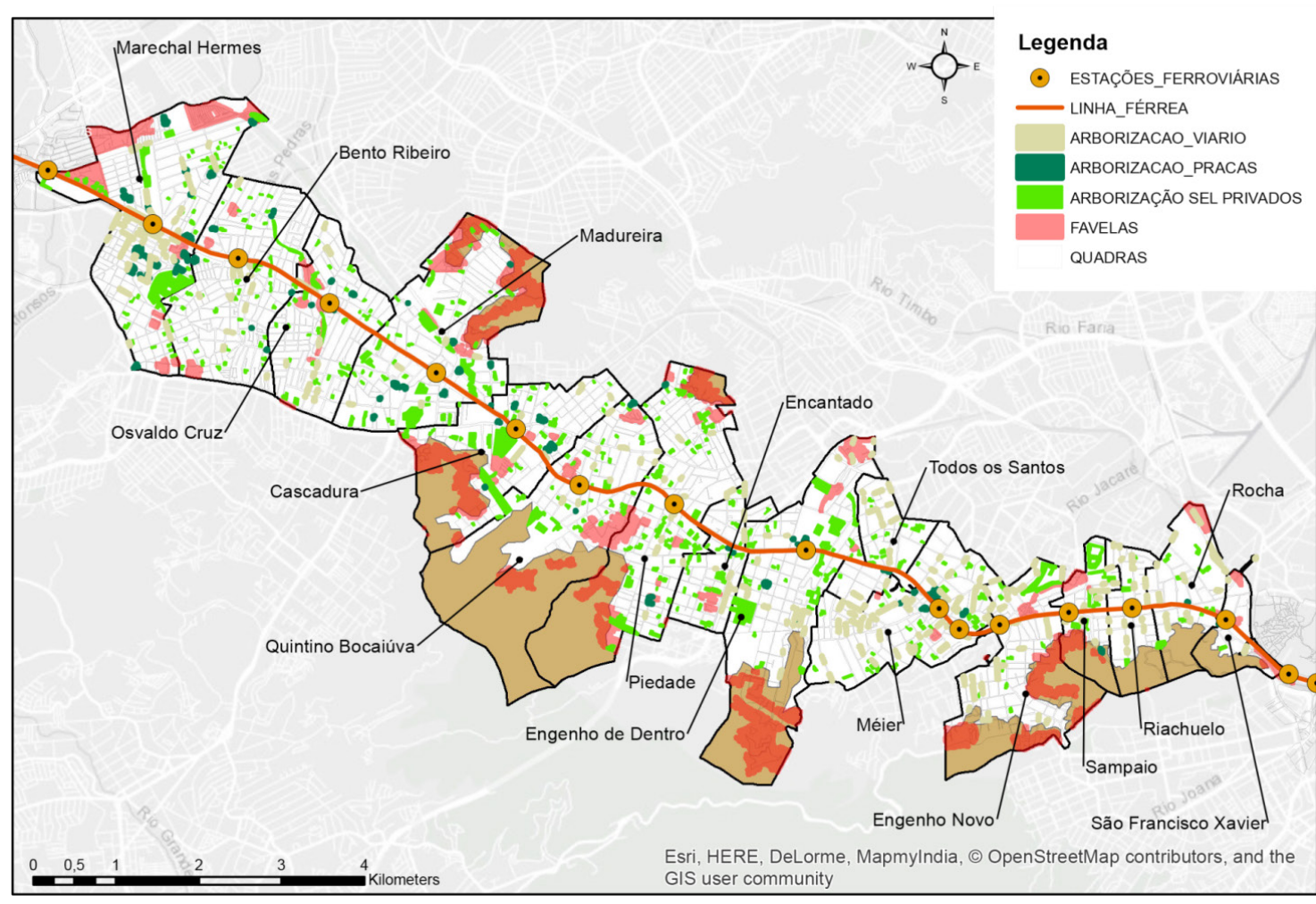

\begin{tabular}{|c|c|c|c|c|c|c|c|c|c|}
\hline \multicolumn{10}{|c|}{ TABELA QUANTITATIVA MASSA ARBÓREA BAIRRO A BAIRRO } \\
\hline BAIRROS & ÁREA(ha) & HABITANTES & DENS.POP. (Hab./ha) & $\begin{array}{c}\text { PRAÇAS / PARQUES } \\
\text { E LARGOS (ha) }\end{array}$ & $\%$ & VIÁRIO (ha) & $\%$ & SEL PRIVADOS (ha) & $\%$ \\
\hline MARECHAL HERMES & 388,00 & 48061,00 & 123,80 & 2,27 & 9 & 4,29 & 17 & 18,23 & 74 \\
\hline BENTO RIBEIRO & 303,00 & 43707,00 & 144,25 & 0,22 & 3 & 0,97 & 14 & 5,62 & 83 \\
\hline OSVALDO CRUZ & 207,00 & 34040,00 & 164,44 & 0,06 & $<1$ & 0,95 & 15 & 5,32 & 84 \\
\hline MADUREIRA & 378,00 & 50106,00 & 132,56 & 0,46 & 2 & 0,33 & 1 & 19,19 & 97 \\
\hline CASCADURA & 284,00 & 34456,00 & 121,32 & 0,43 & 2 & 0,37 & 2 & 14,46 & 96 \\
\hline QUINTINO & 432,00 & 31185,00 & 72,19 & 0,12 & 1 & 0,44 & 5 & 8,53 & 94 \\
\hline PIEDADE & 388,00 & 43378,00 & 111,80 & 0,23 & 1 & 0,62 & 4 & 14,11 & 95 \\
\hline ENCANTADO & 106,00 & 15021,00 & 141,71 & 0,02 & $<1$ & 0,88 & 17 & 4,15 & 82 \\
\hline ENGENHO DE DENTRO & 392,00 & 45540,00 & 116,17 & 0,64 & 3 & 1,3 & 6 & 18,27 & 91 \\
\hline TODOS OS SANTOS & 101,00 & 24646,00 & 244,02 & 0,08 & 2 & 0,97 & 31 & 2,04 & 67 \\
\hline MÉIER & 247,00 & 49828,00 & 201,73 & 0,93 & 9 & 4,09 & 39 & 5,26 & 52 \\
\hline ENGENHO NOVO & 264,00 & 42172,00 & 159,74 & 0 & 0 & 2,57 & 33 & 5,2 & 67 \\
\hline SAMPAIO & 88,00 & 10895,00 & 123,81 & 0,06 & 1 & 0,46 & 8 & 4,87 & 91 \\
\hline RIACHUELO & 93,00 & 12653,00 & 136,05 & 0 & 0 & 1,2 & 57 & 0,88 & 43 \\
\hline $\mathrm{ROCHA}$ & 131,00 & 8766,00 & 66,92 & 0,03 & $<1$ & 1,43 & 37 & 2,38 & 63 \\
\hline SÃO FRANCISCO XAVIER & 65,00 & 8343,00 & 128,35 & 0,01 & 1 & 0,33 & 61 & 0,2 & 39 \\
\hline TOTAL & 3867,00 & 502797,00 & 121,61 & 5,56 & 3,5 & 21,2 & 13,5 & 128,71 & 83 \\
\hline
\end{tabular}

Figura 25 - Mapeamento da massa arbórea dos sistemas de espaços livres de caráter privado.
Tabela 2 - Tabela síntese gerada a partir do mapeamento da arborização dos sistemas de espaços livres. 


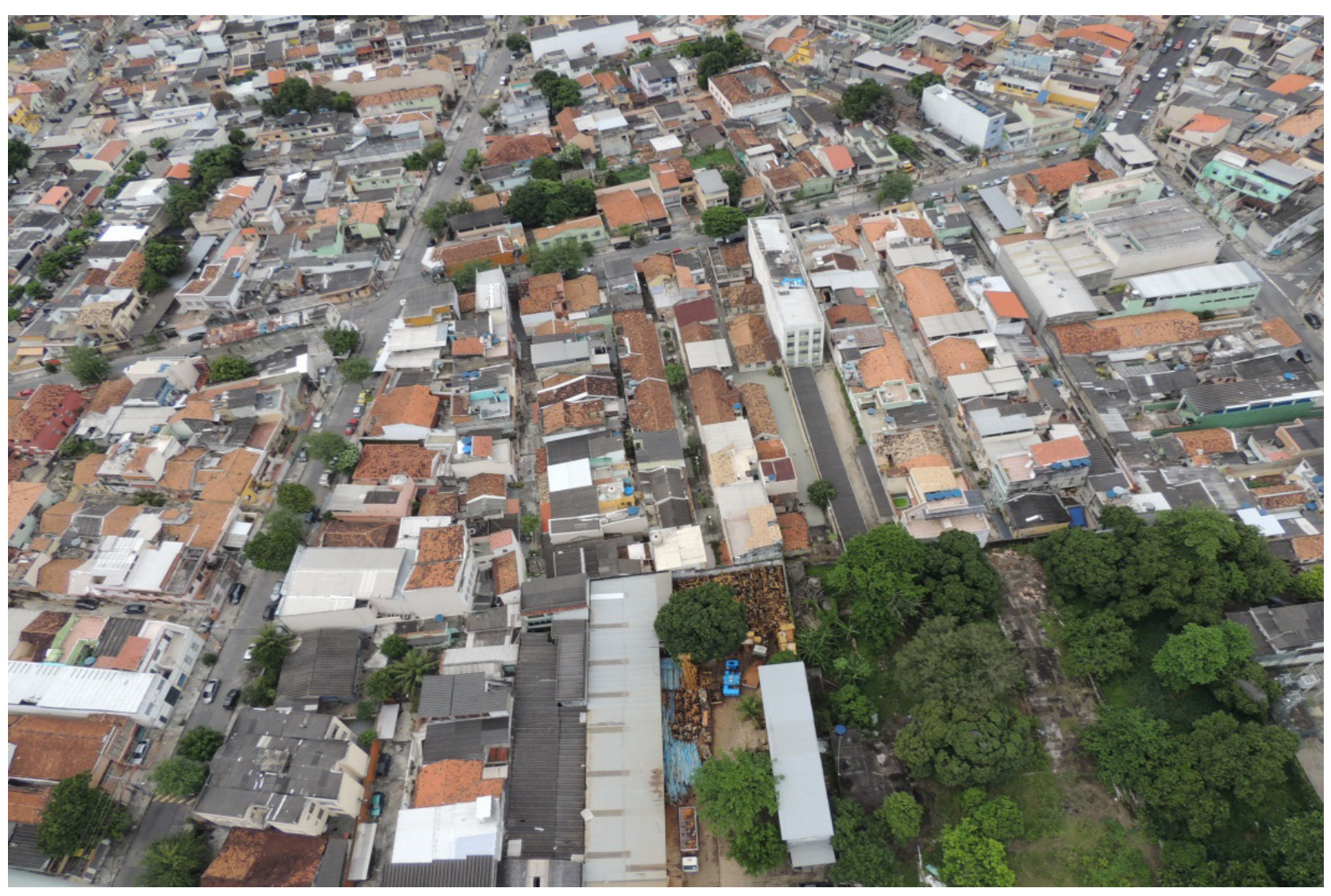

Figura 26 - Manutenção da arborização em lotes privados. Fonte: Acervo SEL-RJ, 2017.

- Grandes lotes pertencentes a instituições de ensino ou saúde que são largamente arborizados;

- Considerável quantidade de lotes não edificados que preservam a arborização existente.

A partir dos fatores considerados para o mapeamento das áreas arborizadas dos espaços privados, definiram-se oito categorias principais para os espaços mais representativos e que preservam considerável massa arbórea, conforme pode ser visto no Quadro 1:

\section{CONCLUSÃO}

O artigo em tela buscou, através de uma análise aprofundada dos espaços livres e do seu tratamento com vegetação, demonstrar que ainda é possível verificar, na cidade do Rio de Janeiro, considerável superfície de espaços livres privados no subúrbio ferroviário e que tais áreas conservam um percentual significativo de arborização, representando uma importante característica a ser observada. Dentro desse contexto, esses espaços se tornam qualificados por contribuir para a qualidade dos bairros onde se 
Quadro 1 - Categorização dos espaços livres privados a partir do mapeamento da arborização existente.

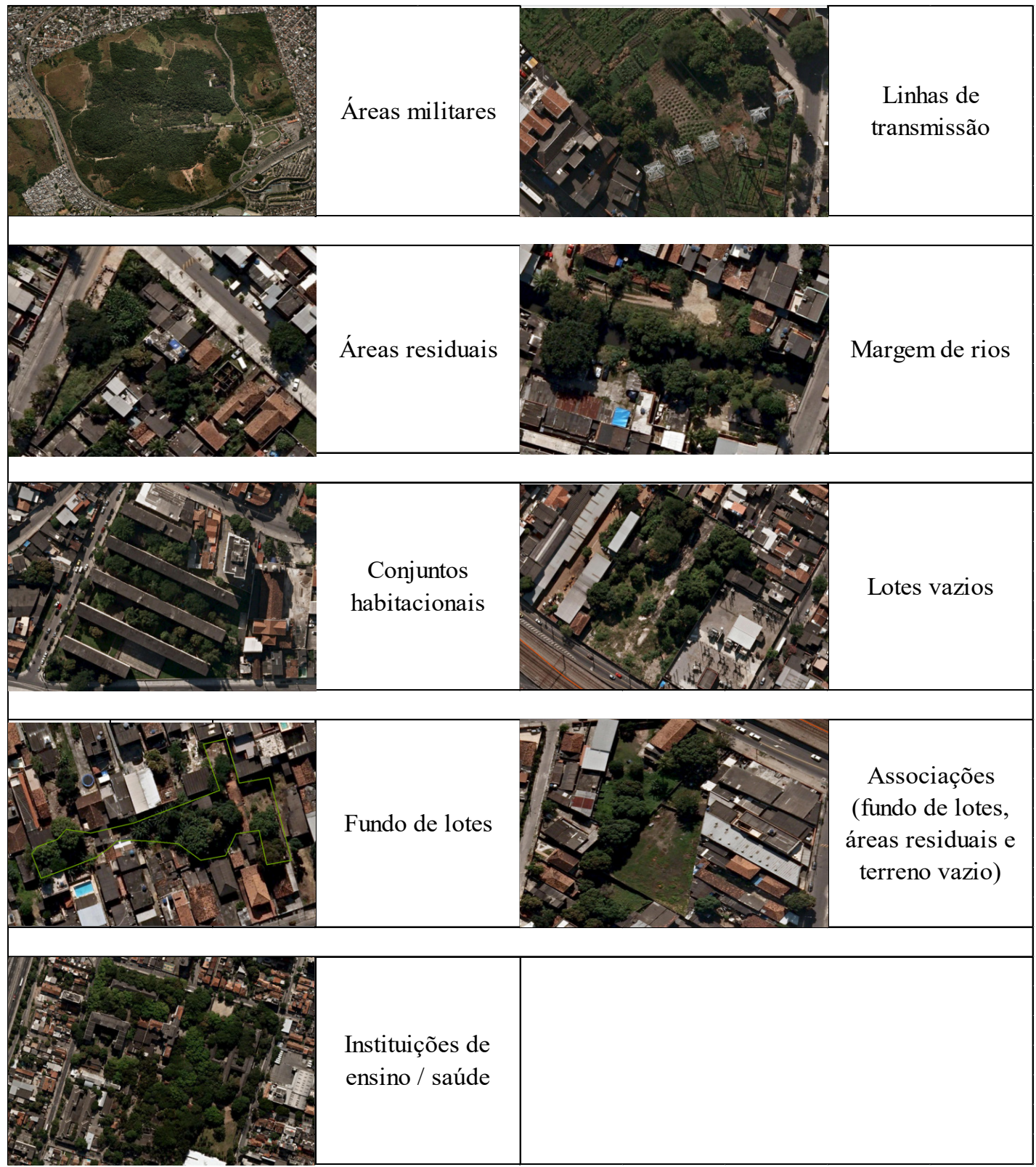


inserem, sendo uma alternativa de espaços permeáveis capazes de contribuir para a melhoria das condições sociais e ambientais e um importante patrimônio a ser preservado.

A análise realizada dos espaços livres, na área de estudo, demonstra que os padrões observados por Macedo et al (2009) sobre o sistema de espaços livres quer públicos ou privados, nas cidades brasileiras, são, de fato, identificados com clareza no subúrbio da cidade do Rio de Janeiro: o primeiro padrão ressalta a escassez de espaços livres públicos devidamente qua1lificados referindose tanto quanto às calçadas e ruas quanto às estruturas de praças e parques. O segundo padrão diz respeito ao reduzido tamanho de espaços livres privados não edificados ou não pavimentados.

No caso particular de ocupação das praças do subúrbio, percebese que o jogo do poder da gestão pública em diferentes tempos e o não aprofundamento jurídico sobre o campo do urbanismo e suas reais necessidades acabam por permitir a abertura de brechas que possibilitam a administração municipal utilizar-se de decretos e dessa forma suplantar as diretrizes urbanísticas contidas no Plano Diretor, que são as ferramentas legais capazes de zelar pela preservação e manutenção dos espaços públicos. Dessa maneira, os poucos espaços existentes acabam por ser suplantados para que se possa atender a outras demandas emergenciais como serviços e equipamento de educação e saúde.

Além de ressaltar a carência de espaços públicos de recreação estruturados capazes de atender à demanda por lazer dos subúrbios, o mapeamento arbóreo realizado nesse estudo evidencia a importância da manutenção dos espaços privados, apesar de dimensões por vezes reduzidas, e de sua arborização, que contribuem de maneira compensatória à carência de áreas públicas arborizadas. A análise também pode ser um importante instrumento na avaliação individualizada da conformação de cada bairro estudado, sendo possível, através da correlação das áreas apresentadas, a identificação de potencialidades e deficiências, no que diz respeito à arborização dessas regiões.
Com o avanço das discussões e da valorização das questões ambientais, se torna adequado considerar como área verde todas as áreas significativamente vegetadas tanto de propriedade pública ou privada. Tal afirmação intenta permitir, desta forma, a valorização do interesse público sobre a proteção ambiental incidente também sobre imóveis privados. Nesse contexto, a partir dos resultados obtidos, comprova-se de fato a importância dos espaços livres privados para a manutenção da vegetação no recorte espacial analisado do subúrbio ferroviário.

Os dados gerados nessa pesquisa podem ainda ser confrontados com novos mapeamentos que poderão ser realizados, tendo como base mapas e ortofotos dos anos seguintes. Essa comparação é capaz de avaliar o aumento ou a supressão da vegetação existente, tanto no espaço livre público quanto no privado. Da mesma forma, as informações e dados obtidos através dessa análise podem ser considerados na formulação de legislações urbanísticas que regulamentam o uso e ocupação do solo em espaços privados e públicos nos bairros localizados na região estudada: como a preservação da proporção de, no mínimo, 50\% da área de ocupação do lote com fins de arborização, mesmo que venha a ser modificada a sua tipologia construtiva. Torna-se urgente ainda a recomendação de incremento da arborização nos espaços públicos assim como a criação de novos espaços, como praças e parques que contenham no mínimo $50 \%$ de áreas arborizadas em seu interior, incluindo as circulações, mesmo nos casos onde existam elementos construídos para sombreamento (VASCONCELLOS, 2006).

Em climas com características de temperatura e umidade como os da Cidade do Rio de Janeiro a incidência de arborização se constitui em demanda de conforto e bem estar, justificando a ampliação de estudos como os demonstrados nesse artigo para outros bairros e regiões da Cidade. 


\section{ReferênCIAS Bibliográficas}

ABREU, Maurício de Almeida. Evolução urbana do Rio de Janeiro. 4. ed. Rio de Janeiro: Instituto Pereira Passos, 2013.

BARRA, Eduardo; TÂNGARI, Vera Regina; SCLEE, Mônica Bahia; BATISTA, Márcia Nogueira (ed.). A vegetação nativa no planejamento e no projeto paisagístico. Rio de Janeiro: RioBooks, 2015.

BUENO, Laura Machado de Mello; TÂNGARI, Vera Regina; PEREIRA, Jonathas Magahães; PEZZUTO, Claudia Coutrim; MONTEZUMA, Rita de Cássia Martins; REGO, Andrea de Queiroz. Mudanças climáticas e as formas de ocupação urbana: processo de criação de cenários socioambientais. Paisagem e Ambiente, São Paulo, n. 30, p. 123-136, 2012 CAMPOS, Ana Cecília; QUEIROGA, Eugênio Fernandes; GALENDER, Fany; DEGGREAS, Helena Napoleon; AKAMINE, Rogério; MACEDO, Sílvio Soares; CUSTÓDIO, Vanderli (org.). Sistemas de espaços livres: conceitos, conflitos e paisagens. São Paulo: Editora Fauusp, 2011 CAMPOS, Ana Cecília; QUEIROGA, Eugênio Fernandes; GALENDER, Fany; DEGGREAS, Helena Napoleon; AKAMINE, Rogério; MACEDO, Sílvio Soares; CUSTÓDIO, Vanderli. Quadro do sistemas de espaços livres nas cidades brasileiras, São Paulo: Editora FAUUSP, 2012

COLLINS, Christiane Craseman; COLLINS, George Roseborough. Camillo Sitte: the birth of modern city planning. Mineola: Courier Corporation, 2006.

CULLEN, Gordon. The concise townscape. Oxford: Architectural Press, 1999.

FARAH, Ivete Mello Calil. Arborização pública e desenho urbano na cidade do Rio de Janeiro: a contribuição de Roberto Burle Marx. 1997. Dissertação (Mestrado em Urbanismo) - Faculdade de Arquitetura e Urbanismo, Universidade Federal do Rio de Janeiro, Rio de Janeiro, 1997.

FERNANDES, Nelson da Nóbrega. O rapto ideológico da categoria subúrbio: Rio de Janeiro 1858-1945. Rio de Janeiro: Apicuri, 2011.

FERREIRA, Aurélio Buarque de Holanda. Dicionário Aurélio da língua portuguesa. 5. ed. Curitiba: Positivo, 2010.

FRIDMAN, Fania. Donos do Rio em nome do rei: uma história fundiária da cidade do Rio de Janeiro. Rio de Janeiro: Jorge Zahar, 1999.

INSTITUTO BRASILEIRO DE GEOGRAFIA E ESTATÍSTICA. Sinopse do Censo Demográfico de 2010. Rio de Janeiro, 2011. Disponível em: https://bit.ly/3ah0Cu3. Acesso em: 9 set. 2017 KOSTOF, Spiro. The city shaped: urban patterns and meanings through history. London: Bulfinch Press Book, 1991.

LINS, Antônio J. P. S. Ferrovia e segregação espacial no subúrbio: Quintino Bocaiúva, Rio de Janeiro. In: OLIVEIRA, Márcio Piñon de; FERNANDES, Nelson da Nóbrega (org.). 150 anos de subúrbio carioca. Rio de Janeiro: Lamparina: Faperj: Eduff, 2010. p. 138-160. LYNCH Kevin. The image of the city. Massachusetts: Massachussets Institute of Tech nology Press, 1972.

MACEDO, Sílvio Soares et al. Considerações preliminares sobre o sistema de espaço livres e a constituição da esfera pública no Brasil. In: TÂNGARI, Vera Regina; SCHLEE,
Mônica Bahia; ANDRADE, Rubens de. (org.) Sistema de espaços livres: o cotidiano, ausências e apropriações. Rio de Janeiro: Ed. UFRJ, 2009, p. 60-83.

MAGNOLI, Miranda Maria Esmeralda Martinelli. Espaços livres e urbanização: uma introdução a aspectos da paisagem metropolitana. 1982. Tese (Livre-Docência em Ar quitetura e Urbanismo) - Faculdade de Arquitetura e Urbanismo, Universidade de São Paulo, São Paulo, 1982.

MONTEZUMA, Rita de Cássia Martins; TÂNGARI, Vera Regina; ISIDORO, Inês Azevedo; MAGALHÃES, Aline. Unidades de paisagem como um método de análise territorial: integração de dimensões geo-biofísicas e arquitetônico-urbanísticas, aplicada ao estudo de gração de dimensões geo-biofísicas e arquitetônico-urbanísticas, aplicada ao estudo de planície costeira no Rio de Janeiro In: SEMINARIO NACIONAL SOBRE O TRATAMENTO DE AREAS DE PRESERVAÇÃO PERMANENTE EM MEIO URBANO E RESTRIÇÕES AMBIENTAIS AO PARCELAMENTO DO SOLO, 3., 2014, Belém. Anais [...]. Belém: Editora da UFPA 2014. p. 36-50. v. 1.

MILLER, Robert W.; HAUER, Richard J.; WERNER, Les P. Urban forestry: planning and managing urban greenspaces. Long Grove: Waveland, 2015.

PEREZ, Maurício Dominguez. Estado da Guanabara: gestão e estrutura administrativa do governo Carlos Lacerda. 2005. Tese (Doutorado em História Social) - Faculdade de Filosofia e Ciências Sociais, Universidade Federal do Rio de Janeiro, Rio de Janeiro, 2005. QUEIROGA, Eugênio Fernandes; BENFATTI, Denio Munia. Sistemas de espaços livres urbanos: construindo um referencial teórico. Paisagem e Ambiente, São Paulo, n. 24, p. 81-87, 2007.

REIS, José de Oliveira. O Rio de Janeiro e seus prefeitos: evolução urbanística da cidade. Rio de Janeiro: Prefeitura do Rio de Janeiro, 1977.

SANTOS, Milton. A urbanização brasileira. São Paulo: Edusp, 2008

TÂNGARI, Vera Regina. Open Space Systems in Rio de Janeiro: the public and private spheres reflected in the urban landscape. In: ALVARES, Lucia Capanema; BARBOSA, Jorge Luiz (ed.). Urban public spaces: From Planned Policies to Everyday Politics (illustrated with Brazilian case studies). Cham: Springer, 2018. p. 109-126.

TÂNGARI, Vera Regina. Um outro lado do Rio. 1999. Tese (Doutorado em Arquitetura e Urbanismo) - Faculdade de Arquitetura e Urbanismo, Universidade de São Paulo, 1999. TÂNGARI, Vera Regina; CARDEMAN, Rogério Goldfeld. Técnicas de simulação para analisar as transformações da forma urbana, da paisagem e do microclima em Vargem Grande, Rio de Janeiro/RJ, Brasil. Thésis, Rio de Janeiro, v. 1, n. 2. p. 229-245, 2016.

TÂNGARI, Vera Regina; SCHLEE, Mônica Bahia; ANDRADE, Rubens de. (org.) Sistema de espaços livres: o cotidiano, ausências e apropriações. Rio de Janeiro: UFRJ, 2009.

VASCONCELLOS, Virginia Maria N. O entorno construído e o microclima de praças em cidades de clima tropical quente e úmido: uma contribuição metodológica para o projeto bioclimático. 2016. Tese (Doutorado em Arquitetura e Urbanismo) - Faculdade de Arquitetura e Urbanismo, Universidade Federal do Rio de Janeiro: PROARQ/UFRJ, 2016. 


\section{Bruno Ragi Eis Mendonça}

Universidade Federal do Rio de Janeiro (UFRJ), Faculdade de Arquitetura e Urbanismo (FAU), Programa de Pós-Graduação em Arquitetura (PROARQ)

Av. Pedro Calmon, 550 - Cidade Universitária da Universidade Federal

do Rio de Janeiro, Rio de Janeiro - RJ, 21941-485, Brasil

Orcid: https://orcid.org/0000-0002-4257-3371

E-mail: brunoragiarq@gmail.com

\section{Vera Regina Tângari}

Universidade Federal do Rio de Janeiro (UFRJ), Faculdade de Arquitetura e Urbanismo (FAU), Programa de Pós-Graduação em Arquitetura (PROARQ)

Av. Pedro Calmon, 550 - Cidade Universitária da Universidade Federal do Rio de Janeiro, Rio de Janeiro - RJ, 21941-485, Brasil.

Orcid: https://orcid.org/0000-0003-4608-7909

E-mail: vtangari@gmail.com

Virgínia Maria Nogueira Vasconcellos

Universidade Federal do Rio de Janeiro (UFRJ), Faculdade de Arquitetura e Urbanismo (FAU), Programa de Pós Graduação em Arquitetura (PROARQ)

Av. Pedro Calmon, 550 - Cidade Universitária da Universidade Federal do Rio de Janeiro, Rio de Janeiro - RJ, 21941-485, Brasil.

Orcid: https://orcid.org/0000-0003-0740-8474

E-mail: virginia.vasconcellos@gmail.com

Nota do editor

Submetido em: 15/08/2019

Aprovado em: 04/03/2020

Revisão do texto: Tikinet 